\title{
A!
}

This is an electronic reprint of the original article.

This reprint may differ from the original in pagination and typographic detail.

Tripathi, Tripurari; Karppinen, Maarit

\section{Atomic layer deposition of p-type semiconducting thin films: a review}

Published in:

Advanced Materials Interfaces

DOI:

10.1002/admi.201700300

Published: 22/12/2017

Document Version

Peer reviewed version

Published under the following license:

CC BY-NC-ND

Please cite the original version:

Tripathi, T., \& Karppinen, M. (2017). Atomic layer deposition of p-type semiconducting thin films: a review. Advanced Materials Interfaces, 4(24), [1700300]. https://doi.org/10.1002/admi.201700300

This material is protected by copyright and other intellectual property rights, and duplication or sale of all or part of any of the repository collections is not permitted, except that material may be duplicated by you for your research use or educational purposes in electronic or print form. You must obtain permission for any other use. Electronic or print copies may not be offered, whether for sale or otherwise to anyone who is not an authorised user. 


\title{
Atomic layer deposition of p-type semiconducting thin films: a review
}

\author{
T. S. Tripathi and M. Karppinen* \\ Department of Chemistry and Materials Science, Aalto University, \\ P.O. Box 16100, FI-00076 Espoo, Finland \\ E-mail: maarit.karppinen@aalto.fi
}

\begin{abstract}
Semiconductors such as elemental silicon allowing both p-type and n-type doping are the backbone of current microelectronics industry, while the continuous progress in the fabrication techniques has been the key for the ever-increased integration density and device miniaturization. Similarly, in the strongly emerging field of transparent electronics both p-type and n-type compound semiconductors are needed that moreover should be transparent within the entire visible spectral range. Atomic layer deposition (ALD) has been the thin-film deposition method of choice for a number of challenging applications in microelectronics, and it would be highly relevant technology for the transparent electronics as well. Currently the appropriate p-type semiconducting compounds are far outnumbered by the n-type compounds. Hence there is an obvious quest for high-quality thin films of new p-type compound semiconductors. This is clearly seen in the increasing number of annually published ALD papers on p-type semiconducting materials. In this overview our intension is to briefly present the current state of research in the field by $(i)$ summarizing the ALD processes so far developed for the various p-type (transparent) conducting material candidates, and (ii) highlighting the most prominent electrical transport and optical properties achieved for these thin films.
\end{abstract}

\section{Introduction}

\subsection{Quest for New Transparent p-type Semiconducting Compounds}

An important characteristics of the conventional semiconductor materials such as silicon and germanium is their inherent aptitude for both p-type and n-type doping in the same parent material; this has been the basis for the numerous well-known technological breakthroughs in microelectronics over the years. To realize the same pace of development in the strongly emerging field of transparent electronics, it would be extremely desirable to find new compound semiconductor materials that are not only optically transparent and electrically conducting but also allow both p-type and n-type doping. The difficulty lies in the unorthodox set of properties required for such materials. Firstly, the high electrical conductivity (implying towards metals or semiconductors) and the optical transparency (implying towards insulators) are rarely met in a single material. Secondly, the same material should allow both oxidation and reduction to facilitate both the hole and electron doping.

Another option is to search for pairs of different but mutually compatible p-type and n-type materials. Such p- and n-type semiconductor material pairs are highly demanded - besides the transparent electronics - for other applications as well, e.g., thermoelectrics, electrochromics and memristors. ${ }^{[1-3]}$ To fabricate an analogous hetero transparent $p$ - $n$ junction, the ideal condition would be that the p- and n-type materials do not differ too much in their lattice parameters, and electrical mobility/conductivity and optical transparency values. However, these preferences are not constraints for the fabrication, as there are several transparent $\mathrm{p}$-n heterojunctions reported for materials with significantly different lattice parameters. ${ }^{[4]}$ For heterojunction devices the interface is usually very sharp (even on atomic scale). The large difference in lattice parameters or electrical conductivities could lead to depressed device performance as a result of strain-relaxed dislocation 
defects and/or resistive heating due to charge accumulation at the interfaces. Similarly the large difference in optical transparency may not optimally serve the purpose of a highly transparent active device. ${ }^{[5]}$

In an ideal case, the two semiconducting materials would also possess, e.g., similar thermal expansion coefficients and fabrication temperatures. For example, when exposed to too high process temperatures or extended processing periods, the more temperature-sensitive material may be oxidized or reduced, ${ }^{[6]}$ leading to the formation of unintended impurity phases or interfacial layers, detrimental to the device performance. Similar fabrication temperatures could also be useful for in-situ fabrication of the whole p-n junction device. For an efficient operation of a bipolar device, a long lifetime of minority charge carriers is needed which in turn would ideally require single crystal features for the materials. However, use of single crystal materials would be costprohibitive for large-area applications. ${ }^{[7]}$ The interface properties need to be understood for improved bipolar oxide hetero-structure diodes. It has been observed that for type-II (staggered type) band matching, the interface recombination limits the ideality factor to values around $2{ }^{[8]}$ which ultimately affects the interface recombination velocity. Therefore type-I (straddling type) and also type-III (broken gap type) interfaces for e.g. $\mathrm{CdO} / \mathrm{NiO},{ }^{[9]}$ need to be studied in more detail regarding the relative importance of thermionic, tunnel and recombination currents and their design and control. ${ }^{[5]}$ Charge carrier mobility is a key to the enhanced performance of bipolar (and also unipolar) devices. In this respect, multi-anion ( $n$-type) oxides are gaining increasing interest; one of the promising materials is $\mathrm{ZnON}{ }^{[10]}$

Presently, the existing p-type semiconductor compounds are far outnumbered by the n-type compounds especially for the transparent electronics applications largely because of the native intrinsic defects in n-type materials are natural such that extrinsic electron doping makes the n-type material rather stable which is in a striking contrast to the hole doping of p-type materials. In p-type transparent conducting oxides (TCOs) hole conduction is hampered by localized $\mathrm{O} 2 \mathrm{p}$ orbitals and deep valence band maximum (VBM) levels where holes are trapped by oxide ions. There are many prominent n-type transparent conductors (TCs) available, in particular the TCOs such as Sn-doped $\mathrm{InO}_{2}, \mathrm{Al}$-doped $\mathrm{ZnO}$ and $\mathrm{F}$-doped $\mathrm{SnO}_{2}$, but very few p-type counterparts. ${ }^{[11]}$ Therefore there is an urgent quest for new p-type (transparent) conducting (oxide) materials that moreover could be engineered into high-quality thin films and coatings for frontier applications. It should be however emphasized that even though the p-type materials are yet little in number, they have already found their way into many applications, mostly as unipolar or passive components in e.g. light emitting diodes (LEDs), solar cells, transparent conductors and solar water splitting, and many more nextgeneration advanced applications can be expected as summarized in Table 1. High-performing transparent p-n junctions would greatly benefit applications such as large-area inorganic-LED (ILED) applications immensely useful for transparent displays, transparent thin film transistors (TTFTs) and functional 'windows' which are supposed to transmit the visible part of solar radiation while generating electricity by absorption of the UV part of the radiation. In recent years, promising results have been reported such as: highly rectifying $\left(>10^{10}\right)$ oxide $\mathrm{p}-\mathrm{n}$ diodes for $\mathrm{ZnO} / \mathrm{ZnCo}_{2} \mathrm{O}_{4}{ }^{[12]}$ and $\mathrm{ZnO} / \mathrm{NiO}^{[8]}$ pairs, highly rectifying $\left(>10^{9}\right)$ and completely transparent diodes for $\mathrm{ZnO} / \mathrm{CuI}$, ${ }^{[13]}$ and highly transparent $(\sim 80 \%)$ diodes for $\mathrm{SnO} / \mathrm{SnO}_{2}{ }^{[6]}$ with an ideality factor of $\sim 3$ and a large rectification ratio of $\sim 10^{3}$. A recent review by Grundmann and co-workers ${ }^{[9]}$ details the current advances in oxide bipolar electronics. Moreover, breakthroughs in bipolar transparent applications would benefit the unipolar/passive applications as well which are also important for the full realization of transparent electronics. 
Table 1. Examples of application areas that are at different maturity stages but would be potentially benefitting from the progress in the field of p-type semiconductor thin-film materials. Also given is the desired set of physical properties for each application.

\begin{tabular}{|c|c|c|c|}
\hline & Physical properties & Applications & Desired set of properties \\
\hline & High transparency in visible spectrum & Transparent electronics & (1) (2) (3) (4) \\
\hline & Large ON/OFF current ratio & Solar water splitting & (3) (4) 8 \\
\hline & High rectification ratio & Photovoltaic (PV) & (3) (4) (8) (4) \\
\hline p-type & High conductivity/mobility & Flexible electronics & (2) (3) (4) (5) \\
\hline & Low process temperature & Thermoelectricity & (4) (6) (7) \\
\hline & High Seebeck coefficient & Smart Windows & (2) (3) (4) (9) \\
\hline & Low thermal conductivity & Transparent TFT & (1) (2) (4) \\
\hline & High absorption in visible spectrum & Electrochromics & (1) (2) (3) (4) \\
\hline & Absorption in UV spectrum & Memristors and UV detectors & (2) (3) \\
\hline
\end{tabular}

\subsection{Importance of the Thin-film Fabrication Technique}

For a majority of the existing and future applications of materials in electronics and optics, the active material needs to be fabricated as high-quality thin films or thin conformal coatings. For instance, for the metallic seed layer depositions in microelectronics for interconnect applications the conventional physical vapor deposition (PVD) technology is used. ${ }^{[14]}$ However, for layers of thickness less than $\sim 50 \mathrm{~nm}$ this technology is not viable due to conformality issues. The chemical vapor deposition (CVD) technology has been thought off as a way forward to overcome this problem but the difficulties in controlling the nucleation and interfacial adhesion of the metals to the common barrier metals on various substrates, and the toxicity, limited availability and arduous handling of precursors have made this as a partial success only. ${ }^{[15,16]}$

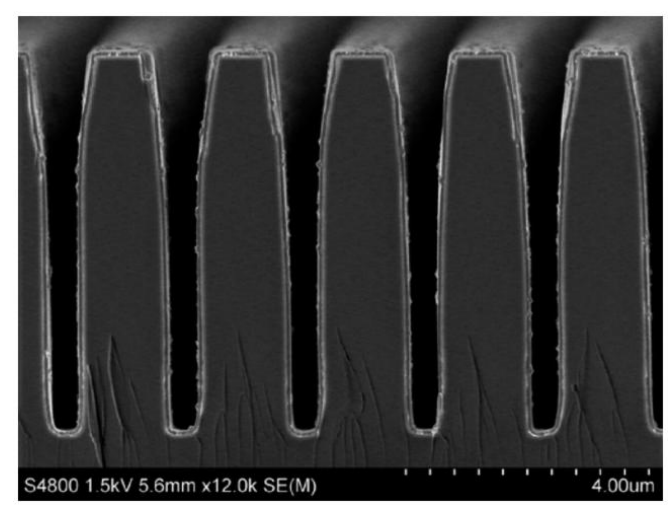

Figure 1. Scanning electron microscopy image of atomic layer deposited germanium antimony telluride coating, showing extreme conformality on a high-aspect-ratio substrate. Reproduced with permission. ${ }^{[19]}$ Copyright 2009, American Chemical Society.

The state-of-the-art thin-film technology, i.e. atomic layer deposition (ALD), ${ }^{[17,18]}$ already utilized in advanced applications to deposit a wide range of functional inorganic materials is in general superiorly suited to address most if not all of the challenges faced by the thin-film fabrication technique in frontier electronics and optics applications. It is based on successive selflimiting surface reactions of separately introduced gaseous precursor pulses, and produces thin films and coatings of well-defined composition, density, thickness and uniformity on complex 
geometries. Thin films fabricated by ALD are highly conformal (Figure 1), following nearly perfectly even extremely complex-shaped 3D surface architectures down to nanometer precision. ${ }^{[19-}$ ${ }^{21]}$ A well-known example showing the reliability and industrial feasibility of the ALD technique is the fabrication of $\mathrm{HfO}_{2}$-based gate dielectrics in Intel's Xeon microprocessors, in which ultrathin and pin-hole free films are required. The aforementioned widely documented capabilities of the ALD technique would be of fundamental importance in the emerging field of TCO thin-film technology as well, considering e.g. the important aspects related to surface passivation, defect chemistry and morphological properties. The attractive prospects for future applications have indeed triggered the recent efforts in ALD research on the topic, as clearly seen from the increasing trend of annually published ALD papers on p-type semiconductor materials in Figure 2.

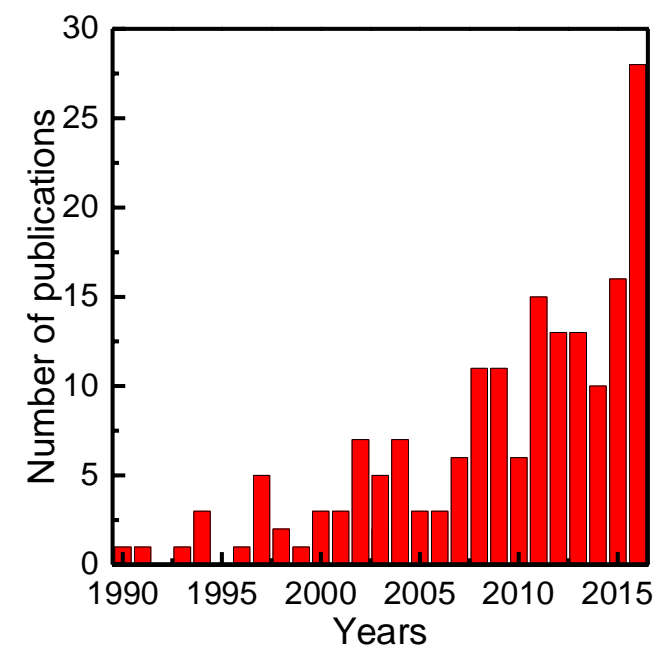

Figure 2. Number of papers annually published for p-type semiconducting thin films fabricated by ALD; the materials counted as p-type semiconductors are the same as presented in Tables 2-4.

\subsection{Scope of the Present Review}

Despite the rapidly growing interest on the topic, there are no comprehensive reviews on the use of ALD in the deposition of p-type conducting thin films. Therefore, it is the aim of this overview to present the current state of research in the field and in particular, $(i)$ summarize the ALD processes so far developed for the various p-type (transparent) conducting material candidates, and (ii) discuss the electrical transport and optical properties of the thin films so far fabricated via these processes. Our intension is to highlight the wide range of p-type materials that can be fabricated by ALD, and illustrate both the advantages and limitations of ALD in the application space of these materials. Before addressing these main issues we will in the following devote short chapters to the current state-of-the-art in the development of (transparent) conducting compounds (Chapter 2) and to the basics of the ALD technique (Chapter 3). In Chapters 4 and 5, respectively, we then summarize and discuss the existing ALD processes for the p-type semiconducting compounds and the electrical transport and optical properties realized for these films, while Chapter 6 is a short summary of the current state and an outlook for the future perspectives and challenges in this scientifically exciting and industrially important field.

\section{Brief Account of the Status of Transparent Semiconducting Compounds}

\subsection{Electron-doped Materials}

The literature on transparent and electrically conductive materials is vast, but currently only few materials have reached the level of industrial interest. Historically, the very first TCO thin-film material reported was $\mathrm{CdO}$; it was fabricated by Badeker ${ }^{[22]}$ in 1907 by thermally oxidizing 
vacuum-sputtered $\mathrm{Cd}$ metal films. Cadmium oxide is still of scientific interest because of its high electron mobility, but the toxicity of cadmium has held back its widespread use. ${ }^{[23,24]}$ Another early TCO material candidate, antimony-doped tin oxide $\left(\mathrm{Sb}: \mathrm{SnO}_{2}\right)$ was used as transparent defroster coatings in aircraft windshields during the World War II. ${ }^{[25]}$ Currently, Sn-doped indium oxide ( $\mathrm{Sn}: \mathrm{In}_{2} \mathrm{O}_{3}$; also known as indium-tin-oxide or ITO) captures more than $90 \%$ of the display market owing to its high conductivity up to $\sim 10^{4} \mathrm{~S} \mathrm{~cm}^{-1}$, greater than $80 \%$ optical transmittance and ease of fabrication. ${ }^{[26]}$ The most serious issue concerning the future role of $\mathrm{Sn}: \mathrm{In}_{2} \mathrm{O}_{3}$ in transparent electronics and other mass applications is the price of the rather rare indium metal which has been continuously increasing in the last two decades. Therefore intensive research efforts have been devoted to explore e.g. F-doped $\mathrm{SnO}_{2}$, Al-doped $\mathrm{ZnO}$, and graphene ${ }^{[27]}$ as possible alternatives to $\mathrm{Sn}: \mathrm{In}_{2} \mathrm{O}_{3}$. All the aforementioned most promising and thoroughly investigated TCO compounds are n-type materials, and thus not further discussed in the present paper. There are however comprehensive ALD reviews for some of these materials. ${ }^{[28,29]}$

\subsection{Hole-doped Materials}

The search for p-type (transparent) conducting materials (Table 2) is more challenging owing to the intrinsic electronic structures of the candidate materials that typically lead to a strongly localized valence band. ${ }^{[30]}$ The elaborate description of the electrical conduction in p-type oxide semiconductors is beyond the context of this review; for interested readers we recommend e.g. the review by Wang et al. ${ }^{[31]}$ on the recent development of p-type oxide semiconductor materials. In short, the following two main issues should be considered: $(i)$ formation energy of native acceptors (holes), and (ii) configuration of the transport path of the carriers. In n-type oxides the native electron donors are the anion (oxygen) vacancies which have low energy of formation and thus donate enough electrons for conduction, and the electron-transport path in the conduction-band minimum is mainly composed of cation (metal) $s$ orbitals that are spatially spread thus facilitating the low effective mass and high mobility of electrons. In contrast, in p-type materials the native acceptors are the cation (metal) vacancies which have relatively high energy of formation and also get annihilated by the electrons donated by the native donors. Thus, the concentration of holes may not be high enough for the conduction of electricity. Moreover, the hole transport path in the valence band maximum is composed mainly of anisotropic and localized oxygen $2 p$ orbitals which increases the effective mass of holes thus often leading to the low hole mobility in p-type oxides.

To alleviate the problem of localized states in the valence band maximum, Kawazoe and coworkers ${ }^{[32]}$ proposed in 1997 the concept of "chemical modification of the valence band" (CMVB) (Figure 3). The strength of the concept was demonstrated by the introduction of the $\mathrm{CuAlO}_{2}$ delafossite as a p-type TCO material for which the hole conductivity arises from the hybridization of $\mathrm{O} 2 p$ orbitals with the closed-shell $\mathrm{Cu} 3 d^{10}$ orbitals. Subsequently, an entire series of p-type $\mathrm{Cu} M O_{2}\left(M=\right.$ e.g. Cr, In, Sc, Y, Ga, B) delafossite TCOs were gradually discovered. ${ }^{[33-40]}$ Furthermore, the concept of CMVB was extended to the chalcogens $(\mathrm{Ch})$ with the anticipation that replacing the electronegative $\mathrm{O}$ by a less electronegative $\mathrm{S}$, Se or Te would allow the enhanced hybridization between the $\mathrm{Cu} 3 d$ orbitals and the $C h p$ orbitals. This resulted in the identification of the two layered systems, $\mathrm{LaCuOCh}(C h=\mathrm{S}, \mathrm{Se}){ }^{[41-44]}$ and $\mathrm{Sr}_{3} \mathrm{Cu}_{2} \mathrm{Sc}_{2} \mathrm{O}_{5} \mathrm{~S}_{2},{ }^{[45]}$ as the most promising new p-type TCO materials in the last decade. Magnesium-doped LaCuOSe holds the record in ptype conductivity $\left(910 \mathrm{~S} \mathrm{~cm}^{-1}\right)$, but its bandgap $(2.8 \mathrm{eV})$ is too small for optical transparency. More recently, a few new families of p-type TCOs such as the $\mathrm{ZnIr}_{2} \mathrm{O}_{4}$ spinels and Cr-based oxides were identified based on the CMVB scheme. ${ }^{[46]}$ 


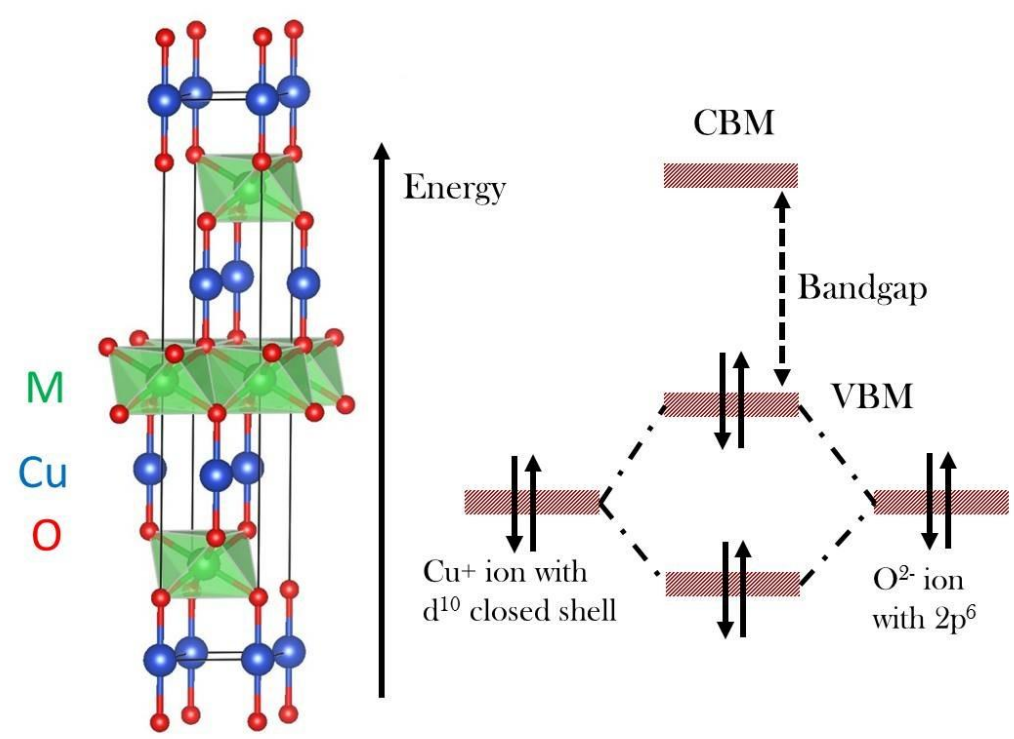

Figure 3. Crystal structure of $\mathrm{Cu} M \mathrm{O}_{2}$ delafossites, and the chemical modification of valence band scheme employed in addressing their p-type conductivity (CBM: conduction band minimum; VBM: valence band maximum).

In the CMVB scheme, the metal cation $d$ levels and the oxide anion $2 p$ levels should have similar energies to realize the hybridization between them. This is a relatively stringent constraint. An alternative approach to the strong hybridization has been suggested as well, where the pseudoclosed $n s^{2}$ orbitals of metal cations and the oxygen $2 p$ orbitals of similar energy levels are hybridized.${ }^{[47-49]}$ Finally we like to mention that for a more thorough view of the existing p-type TCO materials there are several excellent recent reviews on the topic. ${ }^{[9,11,31,50-52]}$

Table 2. Examples of well-established p-type TC/TCO materials.

\begin{tabular}{|c|l|}
\hline Compound & \multicolumn{1}{c|}{ History and development } \\
\hline $\mathrm{Cu}_{2} \mathrm{O}$ & $\begin{array}{l}\text { - first } p \text {-type oxide semiconductor, reported by Grondahl in } 1933 \\
\text { - holds still the best p-type Hall mobility value, which exceeds } 100 \mathrm{~cm}^{2} \mathrm{~V}^{-1} \mathrm{~s}^{-1} \\
\text { - p-type character attributed to the formation of copper vacancies }\end{array}$ \\
\hline $\mathrm{NiO}$ & - first candidate for p-type TCO, reported by Sato et al. in $1993^{[55]}$ \\
\hline $\mathrm{CuAlO}_{2}$ & $\begin{array}{l}\text { - first p-type transparent ternary semiconducting oxide, reported by Kawazoe et al. in } 1997 \\
\text { - discovery led to the } \mathrm{CMVB} \text { concept (chemical modification of the valence band) } \\
\text { - based on } \mathrm{CMVB} \text { several other delafossites } \mathrm{Cu} M \mathrm{O}_{2}(M=\mathrm{Al}, \mathrm{Ga}, \mathrm{In}, \text { etc. }) \text { and other phases } \\
\left(\mathrm{SrCu}_{2} \mathrm{O}_{2}, \mathrm{LaCuOCh}(\mathrm{Ch}=\mathrm{S}, \mathrm{Se}) \text { were identified as TCO candidates }\right.\end{array}$ \\
\hline $\mathrm{SnO}$ & $\begin{array}{l}\text { - promising p-type performance, attracting considerable attention } \\
- \text { discovered based on an alternative design concept, with pseudo-closed } n s^{2} \text { orbitals of metal } \\
\text { cations and oxygen } 2 p \text { orbitals having similar energy levels and forming strong hybridization; } \\
\text { this lifts strong localization effect of oxygen } 2 p \text { orbitals. }\end{array}$ \\
\hline
\end{tabular}

\section{Atomic Layer Deposition in Brief}

The history of the ALD technique is well documented in e.g. the review by Puurunen. ${ }^{[58]}$ It was independently formulated by Aleskovskii and his group in the Soviet-Union in 1960s, ${ }^{[59]}$ and developed by Suntola and co-workers for industrial application in Finland in 1970s. ${ }^{[60,61]}$ In their early patents Suntola and co-workers demonstrated ALD processes based on both element reactants, e.g. the $\mathrm{Zn}+\mathrm{S}$ process for $\mathrm{ZnS}$ films, and compound reactants, e.g. the $(\mathrm{Zn} / \mathrm{Mn}) \mathrm{Cl}_{2}+\mathrm{H}_{2} \mathrm{~S}$ process 
for $(\mathrm{Zn}, \mathrm{Mn}) \mathrm{S}$ films and the $\mathrm{AlCl}_{3}+\mathrm{H}_{2} \mathrm{O}$ process for $\mathrm{Al}_{2} \mathrm{O}_{3}$ films. Initially the technique was introduced as atomic layer epitaxy (ALE) when used to deposit $\mathrm{ZnS}$ thin films for flat panel displays. ${ }^{[60]}$ Later - as most of the important processes are non-epitaxial - the more general name of ALD was adopted. ${ }^{[62]}$

In atomic layer deposition the gas-phase precursors are exposed to the substrate in a sequential manner, separated by a subsequent inert-gas purging. A schematic illustration of the binary ALD process consisting of four fundamental operational steps is shown in Figure 4. The unique feature of ALD is its self-limiting surface chemistry. Upon each precursor exposure, the precursor reacts selectively with the surface functional groups, without self-reacting or decomposing thermally. After the completion of the surface reaction at all accessible surface sites the film growth within that precursor pulse reaches to the saturation. Subsequently, the remaining molecules left in the gas phase after the saturation are purged away, and a second self-limiting precursor is introduced into the reactor chamber. Repeating these sequential precursor/purge exposures to a desired number of times thicker films of precisely controlled thickness can be grown (based on a so-called constant growth-per-cycle or GPC). As the proprietary application, conformal coating on ultrahigh-aspectratio structures (>2000:1) without gradients in thickness or composition is achieved by ALD. ${ }^{[63,64]}$

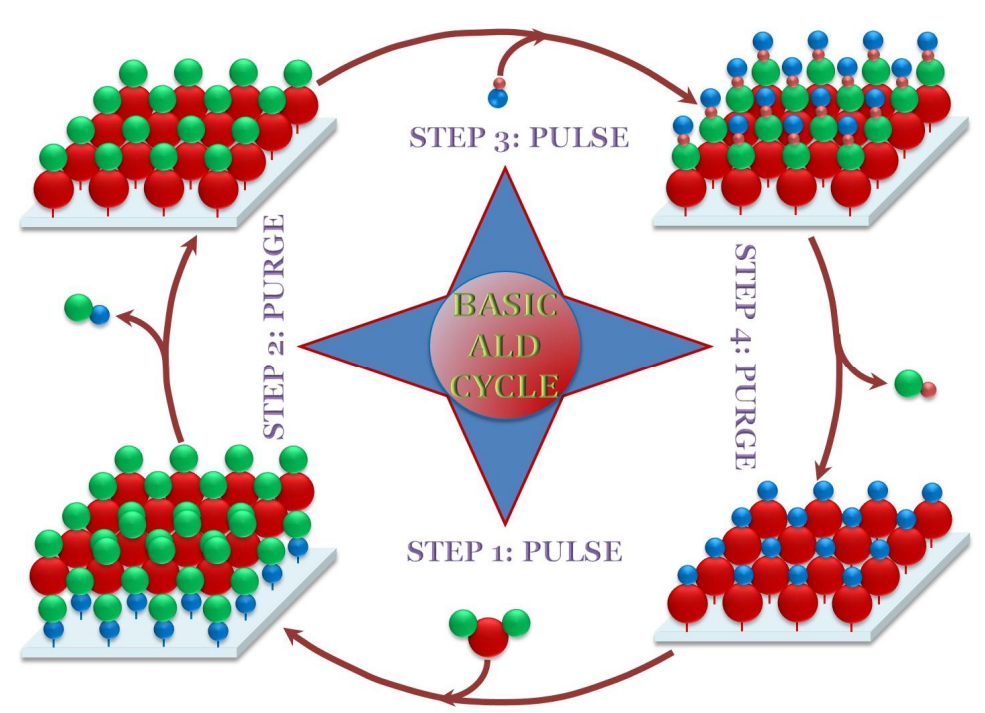

Figure 4. Schematic of a basic ALD cycle. Step 1: introduction of the first precursor; the first precursor is typically a metal-bearing compound which reacts with the already present functional sites on the substrate to give a saturated adsorption growth via chemisorption. Step 2: purge of the side product and excess precursor molecules with an inert gas pulse, e.g. Ar or $\mathrm{N}_{2}$. Step 3: introduction of the second precursor; the second precursor is typically the oxygen, nitrogen or sulphur source, e.g. $\mathrm{O}_{3}, \mathrm{H}_{2} \mathrm{O}, \mathrm{NH}_{3}$, or $\mathrm{H}_{2} \mathrm{~S}$. Step 4: purge of the side product and excess precursor molecules with an inert gas pulse. Repeating these four steps for a desired number of times (depending on the growth rate) films with a precisely controlled thickness can be deposited.

The most unique feature of ALD is its self-limiting film growth nature that allows for excellent composition control, and e.g. well-defined mixtures, nanolaminates, and superlattices by exploiting this characteristics. ${ }^{[65]}$ There are two common indicators that are expected for an ideal ALD process: $(i)$ saturation of surface reactions such that an increase in the precursor pulse length does not increase the GPC value at the given deposition temperature, and (ii) linear film growth at the given deposition temperature such that the resultant film thickness is perfectly controlled by the number of ALD cycles. There are several important experimental parameters that may affect the ideal growth behavior, such as the choice of the substrate material. Also, in ALD literature the socalled ALD temperature window where a constant GPC is observed is often discussed. There are however many useful processes for which the self-limiting growth is satisfied and the growth of high-quality thin films is possible in a perfectly controlled atomic layer-by-layer manner at several 
different temperatures which do not exhibit the same GPC. Readers interested in the in-depth discussion on the factors affecting the ALD processes could find a number of useful reviews on the topic. ${ }^{[58,62-64,66]}$

Not limited to niche applications, ALD is already explored for a wide range of applications, especially in the semiconductor industry. ${ }^{[67]}$ The majority of ALD materials that have been deposited are metal oxides because of the commercial demand for thin-film dielectrics. ${ }^{[68]}$ While the majority of ALD processes developed to date produce metal oxides, novel applications in areas such as energy storage, ${ }^{[69-72]}$ catalysis, ${ }^{[73,74]}$ and nano-photonics ${ }^{[75]}$ are motivating interest in sulfides as well. For example, earth-abundant sulfide materials are of interest in solar cell applications as potential low-cost alternatives to silicon. ${ }^{[76]}$ Moreover, ALD in combination with its purely organic variant viz. molecular layer deposition (MLD) is also gaining momentum for promising applications. ${ }^{[77]}$

\section{ALD Processes for p-type (Transparent) Semiconducting Compounds}

\subsection{General Observations}

So far, ALD processes have been developed for very few different p-type semiconducting compounds that can be considered as relevant candidates for TC applications. For some of these compounds several alternative processes are known. In Tables 2, 3 and 4, we summarize the ALD parameters used in the processes developed for the different p-type semiconducting binary oxides, ternary oxides and metal sulfides, respectively. The following general points can clearly be concluded from these tables.

1. Binary oxide films greatly outnumber the ternary oxide and metal sulfide films. This may be related to the complexity of the depositions involving more than two precursors and the difficulty in controlling the metal stoichiometry in such depositions.

2. In oxide depositions $\mathrm{O}_{2}, \mathrm{O}_{3}$ or $\mathrm{H}_{2} \mathrm{O}$ is the main oxygen source, whereas for sulfides $\mathrm{H}_{2} \mathrm{~S}$ has been used as the source for sulfur.

3. The GPC values are in maximum in the range of $1-2 \AA /$ cycle which is not very high but may be acceptable depending on the application such as interface passivation layers in solar cells, and deposition of thin insulating layers for transparent $\mathrm{p}-\mathrm{i}$-n diodes and thin electrodes.

4. Deposition temperatures for most of the films are around $200{ }^{\circ} \mathrm{C}$, which is yet acceptable considering the requirements set by the typical polymer substrates such as polyether ether ketone (PEEK), polyethylene terephthalate (PET) and polyimides (e.g. Kapton), needed for the flexible p-type thin-film applications. Also, amorphous materials deposited through lowtemperature processes could bring some advantages (roll-to-roll deposition, amorphous substrates, large area devices, flexible electronics, etc.). A fully amorphous bipolar oxide diode based on zinc-tin-oxide has already been reported. ${ }^{[78]}$

5. Binary as-deposited films are generally crystalline, whereas ternary and quaternary films require an additional post-deposition annealing for crystallization.

6. Films can be deposited on almost all kinds of substrates from silicon to carbon nanotubes and nanopowder samples.

\subsection{ALD of Binary p-type Metal Oxides}

As can be seen from Table 3, there are indeed a number of p-type conducting binary oxide materials for which an ALD process has been developed. However, it is to mention here that even though all the compounds listed in Table 3 have been reported to be p-type conductors in their bulk form, not 
all the thin films grown by ALD have been exclusively investigated for their p-type semiconducting characteristics. In several cases the ALD processes have been rather developed having the eye on other applications and other functional properties such as catalytic activity, barrier layers to stop carrier diffusion, etc. From the TCO application point of view very few have been explored.

Table 3. ALD processes reported for p-type semiconducting binary oxides.

\begin{tabular}{|c|c|c|c|c|c|c|c|}
\hline \multirow{3}{*}{ Material } & \multicolumn{5}{|c|}{ Atomic Layer Deposition } & \multirow{3}{*}{$\begin{array}{l}\text { Cryst. } \\
\text { Req. }\end{array}$} & \multirow{3}{*}{ Ref. } \\
\hline & \multicolumn{2}{|c|}{ Precursor (Subl. temp. $\left.\left({ }^{0} \mathrm{C}\right)\right)$} & \multirow{2}{*}{ Substrate } & \multirow{2}{*}{$\begin{array}{l}\text { Dep. Temp. } \\
\left({ }^{0} \mathrm{C}\right)\end{array}$} & \multirow{2}{*}{ GPC (̊) } & & \\
\hline & Precursor A & Precursor B & & & & & \\
\hline \multirow[t]{4}{*}{$\mathrm{CuO}$} & $\mathrm{Cu}(\text { thd })_{2}(120-160)$ & $\mathrm{O}_{3}$ & $\mathrm{Si}, \mathrm{BSG}$ & $200-260$ & 0.17 & As-dep. & {$[66,79,80]$} \\
\hline & $\mathrm{Cu}(\mathrm{acac})_{2}(140)$ & $\mathrm{O}_{3}$ & $\mathrm{Si}, \mathrm{SLG}$ & $150-250$ & 0.4 & As-dep. & {$[81]$} \\
\hline & $\mathrm{Cu}(\mathrm{dmap})_{2}(65)$ & $\mathrm{O}_{3}$ & $\mathrm{Si}, \mathrm{SLG}$ & $80-140$ & $0.2-0.3$ & As-dep. & [82] \\
\hline & $\mathrm{CuCl}_{(350)}$ & {$\left[\mathrm{O}_{2}+\mathrm{H}_{2} \mathrm{O}\right]$} & $\mathrm{MgO}$ & & $2.0-2.2$ & As-dep. & [83] \\
\hline \multirow[t]{5}{*}{$\mathrm{Cu}_{2} \mathrm{O}$} & $(\mathrm{hfac}) \mathrm{Cu}(\mathrm{I})(\mathrm{dmb})(40)$ & $\mathrm{O}_{3}$ & $\mathrm{Si}, \mathrm{SiO}, \mathrm{SLG}$ & 100 & 0.31 & As-dep. & {$[84,85]$} \\
\hline & \multirow{2}{*}{$\left(\mathrm{nBu}_{3} \mathrm{P}\right)_{2} \mathrm{Cu}(\mathrm{acac})(85-115)$} & \multirow{2}{*}[\mathrm{O}_{2}+\mathrm{H}_{2}\mathrm{O}]{} & $\mathrm{SiO}, \mathrm{Ta}, \mathrm{TaN}, \mathrm{Ru}$ & $100-150$ & 0.10 & As-dep. & [86-89] \\
\hline & & & $\mathrm{SiO}$ & $22-300$ & 0.05 & As-dep. & {$[90,91]$} \\
\hline & $\mathrm{Cu}(\mathrm{dmamb})_{2}(80)$ & $\mathrm{H}_{2} \mathrm{O}$ & $\mathrm{Si} / \mathrm{SiO}$ & $120-240$ & 0.13 & As-dep. & [92] \\
\hline & $(\mathrm{hfac}) \mathrm{Cu}(\mathrm{I})(\mathrm{tmvs})(65)$ & $\mathrm{H}_{2} \mathrm{O}$ & BSG & $150-350$ & 0.25 & & [93] \\
\hline \multirow[t]{12}{*}{$\mathrm{NiO}$} & $\mathrm{Ni}(\mathrm{acac})_{2}(155)$ & \multirow[t]{3}{*}{$\mathrm{O}_{3}(20)$} & \multirow[t]{3}{*}{ SLG } & \multirow[t]{3}{*}{$190-310$} & \multirow[t]{3}{*}{$0.62-0.72$} & \multirow[t]{3}{*}{ As-dep. } & \multirow[t]{3}{*}[94,95]{} \\
\hline & $\mathrm{Ni}(\mathrm{dmg})_{2}(190)$ & & & & & & \\
\hline & $\mathrm{Ni}(\text { apo })_{2}(130)$ & & & & & & \\
\hline & $\mathrm{Ni}(\mathrm{dmamp})_{2}(90-170)$ & $\mathrm{H}_{2} \mathrm{O}$ & $\mathrm{Si}, \mathrm{ZnO}$ nano rod & $100-160$ & $0.8-1.4$ & Amorph. & [96-98] \\
\hline & $\mathrm{Ni}(\mathrm{MeCp})_{2}$ & $\mathrm{H}_{2} \mathrm{O}_{2}$ & $\mathrm{Si}$ & 400 & & Amorph. & [99] \\
\hline & $\mathrm{Ni}(\mathrm{AMD})(125)$ & $\mathrm{H}_{2} \mathrm{O}$ & FTO & 175 & 0.75 & As-dep. & [4] \\
\hline & $\mathrm{Ni}(\mathrm{dmamb})_{2}(90)$ & $\mathrm{H}_{2} \mathrm{O}$ & $\mathrm{Si}$ & 140 & 1.4 & Amorph. & {$[100,101]$} \\
\hline & $\mathrm{Ni}(\mathrm{CpEt})_{2}(40-80)$ & $\mathrm{O}_{3}$ & $\mathrm{Si}$ & $150-300$ & $0.9-0.5$ & As-dep. & {$[102,103]$} \\
\hline & $\mathrm{Ni}(\mathrm{Cp})_{2}(40-90)$ & $\mathrm{O}_{3} ;\left[\mathrm{O}_{3}+\mathrm{H}_{2} \mathrm{O}\right]$ & $\begin{array}{l}\mathrm{Si}, \mathrm{Ni}, \mathrm{Pt}, \mathrm{W}, \\
\text { TiN, AAO, Qz }\end{array}$ & $150-300$ & $3.2-0.3$ & As-dep. & $\begin{array}{l}{[37,104-} \\
108]\end{array}$ \\
\hline & \multirow[t]{2}{*}{$\mathrm{Ni}(\text { thd })_{2}(165)$} & \multirow[t]{2}{*}{$\mathrm{H}_{2} \mathrm{O}$} & $\mathrm{SiO}$ & $205-290$ & $0.2-0.4$ & As-dep. & {$[109,110]$} \\
\hline & & & $\mathrm{G}, \mathrm{MgO}, \mathrm{AlO}$ & $205-275$ & $0.2-0.3$ & As-dep. & {$[111]$} \\
\hline & $\mathrm{Ni}(\mathrm{tBu}-\mathrm{MeAMD})_{2}(125)$ & $\mathrm{H}_{2} \mathrm{O}$ & $\mathrm{Si}$ & 200 & 0.39 & As-dep. & [112] \\
\hline $\mathrm{SnO}$ & $\mathrm{Sn}(\mathrm{dmamp})_{2}(52-70)$ & $\mathrm{H}_{2} \mathrm{O}$ & $\mathrm{Si} / \mathrm{SiO}$ & $90-210$ & $0.61-0.08$ & $\begin{array}{l}\text { Amorph./ } \\
\text { As-dep. }\end{array}$ & {$[113,114]$} \\
\hline \multirow{2}{*}{$\begin{array}{l}\mathrm{a}-\mathrm{TiO}_{2} \\
\text { and } \\
\mathrm{N}: \mathrm{TiO}_{2}\end{array}$} & $\mathrm{TiCl}_{4}$ & $\mathrm{H}_{2} \mathrm{O} ; \mathrm{NH}_{3}$ & $\mathrm{AlO}$ & 300 & 0.30 & As-dep. & [115] \\
\hline & $\mathrm{Ti}\left(\mathrm{N}\left(\left(\mathrm{CH}_{3}\right)_{2}\right)_{4}(75)\right.$ & $\mathrm{H}_{2} \mathrm{O}$ & $\mathrm{Si}$ & $200-250$ & 0.40 & $\mathrm{~N}_{2} /$ Air-400 & [116] \\
\hline \multirow{2}{*}{$\begin{array}{l}\mathrm{Mn}_{2} \mathrm{O}_{3} / \\
\mathrm{Mn}_{3} \mathrm{O}_{4}\end{array}$} & $\mathrm{Mn}(\text { thd })_{3}(133)$ & $\mathrm{O}_{3}$ & $\mathrm{Si}, \mathrm{SLG}$ & $138-257$ & $0.18-0.2$ & As-dep. & [117-119] \\
\hline & $\mathrm{Mn}_{2}(\mathrm{CO})_{10}(40)$ & $\mathrm{O}_{3}$ & $\mathrm{Si}$ & $60-200$ & $0.6-1.5$ & As-dep. & {$[120]$} \\
\hline \multirow{11}{*}{$\begin{array}{l}\mathrm{Fe}_{2} \mathrm{O}_{3} / \\
\mathrm{Fe}_{3} \mathrm{O}_{4}\end{array}$} & $\mathrm{FeCl}_{3}(175)$ & $\mathrm{H}_{2} \mathrm{O}$ & $\mathrm{G} / \mathrm{Pt}, \mathrm{G}, \mathrm{Qz}, \mathrm{FTO}$ & $200-500$ & $0.2-0.6$ & As-dep. & {$[121,122]$} \\
\hline & $\mathrm{Fe}(\mathrm{Cp})_{2}(60-100)$ & $\mathrm{O}_{2}$ & $\mathrm{Si}, \mathrm{AAO}, \mathrm{ALO}$ & $350-600$ & $0.6-1.4$ & As-dep. & [123-129] \\
\hline & & $\mathrm{O}_{3}$ & $\begin{array}{l}\mathrm{ZrO}_{2}, \mathrm{TiO}_{2}, \mathrm{CNT}, \\
\text { Oz. ITO ZnO FTO }\end{array}$ & $200-250$ & $0.2-1.4$ & As-dep. & [130-143] \\
\hline & & {$\left[\mathrm{O}_{3}+\mathrm{H}_{2} \mathrm{O}\right]$} & & 200 & 0.6 & & {$[144,145]$} \\
\hline & $\mathrm{Fe}(\text { thd })_{3}(114-135)$ & $\mathrm{O}_{3}$ & $\mathrm{Si}, \mathrm{ALO}, \mathrm{SLG}, \mathrm{MgO}$ & $138-380$ & $0.11-0.14$ & As-dep. & [146-149] \\
\hline & $\mathrm{Fe}(\mathrm{acac})_{3}(180)$ & $\mathrm{O}_{3}$ & $\mathrm{YSZ}, \mathrm{Si} / \mathrm{SiO}$ & $25-500$ & & As-dep. & {$[150,151]$} \\
\hline & $\mathrm{Fe}_{2}\left(\mathrm{O}^{\mathrm{t} B u}\right)_{6}(100)$ & $\mathrm{H}_{2} \mathrm{O}$ & ALO & & $0.22-0.3$ & Amorph. & [152-156] \\
\hline & $\mathrm{TBF}(65)$ & $\mathrm{O}_{2}$ & $\mathrm{Si} / \mathrm{SiO}$ & $150-400$ & $0.2-1.2$ & As-dep. & {$[157]$} \\
\hline & FeAMD (120) & $\mathrm{H}_{2} \mathrm{O}$ & $\mathrm{Si}$ & & $0.55 \pm 0.05$ & Air-500 & [158] \\
\hline & FeDMP (55) & $\mathrm{H}_{2} \mathrm{O}$ & $\begin{array}{l}\mathrm{Si}, \mathrm{Qz}, \mathrm{FTO}, \text { fused- } \\
\mathrm{Si}\end{array}$ & $65-200$ & $0.6-0.9$ & & [159] \\
\hline & DMAMFc (90) & $\mathrm{O}_{3}$ & $\mathrm{Si} / \mathrm{SiO}$ & $325-450$ & $0.20-1.4$ & As-dep. & {$[160,161]$} \\
\hline $\mathrm{Co}_{3} \mathrm{O}_{4}$ & $\mathrm{CoI}_{2}(465)$ & $\mathrm{O}_{2}$ & $\mathrm{Si} / \mathrm{SiO}, \mathrm{MgO}$ & $475-700$ & $0.8-2.0$ & As-dep. & [162] \\
\hline & $\mathrm{Co}(\mathrm{acac})_{2}(160-180)$ & $\mathrm{O}_{2}$ & $\mathrm{AlO}, \mathrm{AlN} / \mathrm{SiO}$ & 200 & & Air-450 & [163-171] \\
\hline
\end{tabular}




\begin{tabular}{|c|c|c|c|c|c|c|c|}
\hline & $\mathrm{Co}(\mathrm{thd})_{2}(110)$ & $\mathrm{O}_{3}$ & $\begin{array}{l}\mathrm{Si}, \mathrm{SLG}, \mathrm{MgO}, \\
\mathrm{AlO}, \mathrm{STO}\end{array}$ & $114-307$ & 0.2 & As-dep. & {$[172-174]$} \\
\hline & $\mathrm{Co}_{2}(\mathrm{CO})_{8}(30)$ & $\mathrm{O}_{3}$ & $\mathrm{Si}, \mathrm{G}$ & 50 & 6.0 & Air-500 & {$[175]$} \\
\hline & $\mathrm{Co}(\mathrm{Cp})_{2}(80-100)$ & $\mathrm{O}_{3}$ & $\mathrm{Si} / \mathrm{SiO}, \mathrm{SLG}, \mathrm{AlO}$ & $100-400$ & $0.4-0.5$ & As-dep. & [176-178] \\
\hline & $\mathrm{CpCo}(\mathrm{CO})_{2}$ & $\mathrm{O}_{3}$ & CNT & 100 & $0.06-0.08$ & & [179] \\
\hline & CCTBA (50) & $\mathrm{O}_{3}$ & Si-Boron & & 0.83 & As-dep. & {$[180]$} \\
\hline $\mathrm{N}: \mathrm{ZnO}$ & $\mathrm{Zn}\left(\mathrm{C}_{2} \mathrm{H}_{5}\right)_{2}(10) ; \mathrm{NH}_{3}$ & $\mathrm{H}_{2} \mathrm{O}$ & Sapphire, SiO & $100-300$ & & $\mathrm{O}_{2}-1000$ & [181-183] \\
\hline \multirow[t]{3}{*}{$\mathrm{P}: \mathrm{ZnO}$} & $\mathrm{Zn}\left(\mathrm{C}_{2} \mathrm{H}_{5}\right)_{2} ;\left(\mathrm{CH}_{3}\right)_{3} \mathrm{PO}_{4}$ & $\mathrm{O}_{3}$ & $\mathrm{Si} / \mathrm{SiO}$ & 250 & 1.7 & $\mathrm{O}_{2}-500$ & {$[184]$} \\
\hline & $\mathrm{Zn}\left(\mathrm{C}_{2} \mathrm{H}_{5}\right)_{2}$ & $\mathrm{H}_{2} \mathrm{O}$ & P:SOD & 300 & 1.0 & $\mathrm{O}_{2} / \mathrm{N}_{2}-700$ & [185] \\
\hline & $\mathrm{Zn}\left(\mathrm{C}_{2} \mathrm{H}_{5}\right)_{2} ;\left(\mathrm{CH}_{3}\right)_{3} \mathrm{PO}_{4}$ & $\mathrm{H}_{2} \mathrm{O}$ & BSG & $160-220$ & & & {$[186]$} \\
\hline $\mathrm{Cu}: \mathrm{ZnO}$ & $\mathrm{Zn}\left(\mathrm{C}_{2} \mathrm{H}_{5}\right)_{2} ; \mathrm{Cu}(\mathrm{hfac})_{2}$ & $\mathrm{H}_{2} \mathrm{O}$ & & 200 & & $\mathrm{~N}_{2}-300-600$ & [187] \\
\hline \multicolumn{8}{|c|}{ 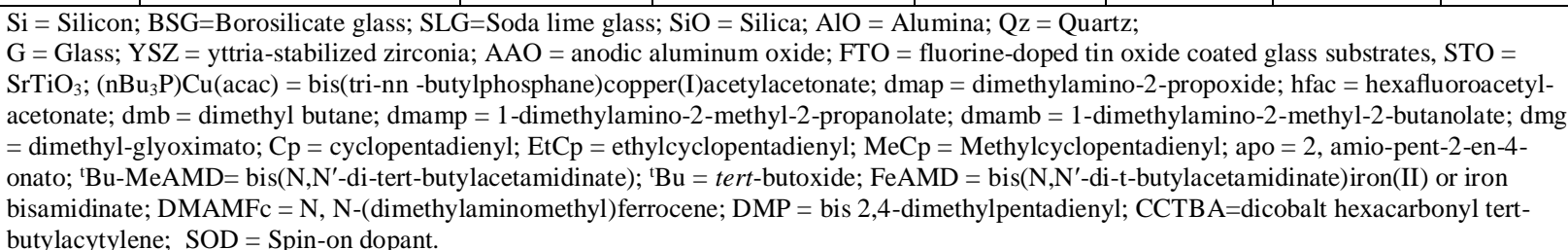 } \\
\hline
\end{tabular}

As was discussed in Chapter 2, SnO has shown promising p-type TCO performance. The relatively high hole mobility in $\mathrm{SnO}$ is largely due to the low defect-formation energy of $\mathrm{Sn}$ vacancies and to the creation of a suitable dispersed valence band maximum by the hybridization of Sn 5 s and oxygen $2 p$ orbitals. Soon after the theoretical discovery of the hole-transporting nature of SnO, p-type TFTs were successfully fabricated (not by ALD) with relatively high hole field effect and Hall mobility values. ${ }^{[188-190]}$ However, $\mathrm{SnO}$ readily transforms to the n-type $\mathrm{SnO}_{2}$ phase. Thus to control the stoichiometry to $\mathrm{SnO}$ is the major challenge in the deposition of SnO. Recently, highquality single-phase $\mathrm{SnO}$ thin films with negligible impurity levels were deposited by ALD at low deposition temperatures of $90-210{ }^{\circ} \mathrm{C}$ using bis(1-dimethyamino-2-methyl-2propoxy)tin(II) and $\mathrm{H}_{2} \mathrm{O}$ as precursors.

Cuprous oxide $\mathrm{Cu}_{2} \mathrm{O}$ is also known as a promising p-type TCO, and it still holds the best p-type Hall mobility value (reported for films deposited by techniques other than ALD), which exceeds $100 \mathrm{~cm}^{2} \mathrm{~V}^{-1} \mathrm{~s}^{-1}$. ${ }^{[4,191]}$ There are several ALD processes reported for $\mathrm{Cu}_{2} \mathrm{O}$, and also for $\mathrm{CuO}$. However, the real p-type transparent device characteristics have yet to be demonstrated for these ALD-fabricated copper oxide films. Besides the p-type semiconductivity, some other potential applications for ALD copper oxide films were recently highlighted. For example, Wang et al. ${ }^{[143]}$ reported the size-selective catalytic growth of nearly $100 \%$ pure carbon nanocoils with copper nanoparticles produced by reduction of ALD-CuO films. When these nanocoils were further coated with magnetic $\mathrm{Fe}_{3} \mathrm{O}_{4}$ or $\mathrm{Ni}$ by ALD the coated nanocoils with coaxial multilayer nanostructures exhibited remarkably improved microwave absorption properties compared to the pristine carbon nanocoils. ${ }^{[139]}$

\subsection{ALD of Ternary p-type Metal Oxides}

As described in Chapter 2, ternary oxides and in particular the delafossites $\mathrm{Cu} M \mathrm{O}_{2}$ where $M$ is a trivalent cation came into the radar to p-type TCOs research when Kawazoe and co-workers in 1997 proposed the design concept based on the hybridization between metal $d$ and oxygen $2 p$ levels. Since then considerable research efforts have been directed towards finding new potential p-type TCO candidates among this family. However, the ALD technique (Table 4) has not been in the very forefront in this research. This we believe is due to the limited availability of precursors and also to the challenges related to the optimization of ALD processes for multimetal systems. However, very recently promising results were obtained even for the quaternary $\mathrm{Cu}(\mathrm{Cr}, \mathrm{Mg}) \mathrm{O}_{2}$ system. ${ }^{[192]}$ The ALD process is based on $\mathrm{Cu}(\text { thd })_{2}$ (thd = 2,2,6,6-tetramethyl-3,5-heptanedionate), $\mathrm{Cr}(\mathrm{acac})_{3}$ (acac = acetyl acetonate) and $\mathrm{Mg}(\mathrm{thd})_{2}$ as metal precursors and ozone as the oxygen source. Smooth and 
homogeneous thin films with an accurately controlled $\mathrm{Mg}$ content were obtained at the deposition temperature of $250{ }^{\circ} \mathrm{C}$. In the deposition super-cycle, $\mathrm{n} *\left[\left(\mathrm{Cu}(\mathrm{thd})_{2}+\mathrm{O}_{3}\right)+3 *\left(\mathrm{Cr}(\mathrm{acac})_{3}+\mathrm{O}_{3}\right)\right]+$ $\left[\left(\mathrm{Cu}(\text { thd })_{2}+\mathrm{O}_{3}\right)+2 *\left(\mathrm{Cr}(\mathrm{acac})_{3}+\mathrm{O}_{3}\right)+\left(\mathrm{Mg}(\mathrm{thd})_{2}+\mathrm{O}_{3}\right)\right]$, the $\mathrm{Mg}$-doping level could be accurately controlled by the choice of $\mathrm{n}$ up to a few mol-\% substitution levels (down to $\mathrm{n} \approx 10$ ). Note that to achieve the $\mathrm{Cu} / \mathrm{Cr}=1$ stoichiometry in the films, three times more $\mathrm{Cr}(\mathrm{acac})_{3}+\mathrm{O}_{3}$ cycles compared to the number of $\mathrm{Cu}(\text { thd })_{2}+\mathrm{O}_{3}$ cycles were required.

Table 4. ALD processes reported for p-type semiconducting ternary and quaternary oxides.

\begin{tabular}{|c|c|c|c|c|c|c|c|}
\hline \multirow{3}{*}{ Material } & \multicolumn{5}{|c|}{ Atomic Layer Deposition } & \multirow{3}{*}{$\begin{array}{l}\text { Cryst. } \\
\text { Req. }\end{array}$} & \multirow{3}{*}{ Ref. } \\
\hline & \multicolumn{2}{|c|}{ Precursor $\left(\right.$ Subl. temp. $\left.\left({ }^{\circ} \mathrm{C}\right)\right)$} & \multirow{2}{*}{ Substrate } & \multirow{2}{*}{$\begin{array}{c}\text { Dep. } \\
\text { Temp. } \\
\left({ }^{0} \mathrm{C}\right)\end{array}$} & \multirow{2}{*}{$\begin{array}{c}\text { GPC } \\
(\AA)\end{array}$} & & \\
\hline & Precursor A & Precursor B & & & & & \\
\hline$\left[\mathrm{CoCa}_{2} \mathrm{O}_{3}\right]_{q} \mathrm{CoO}_{2}$ & $\mathrm{Co}(\text { thd })_{2}(95) ; \mathrm{Ca}(\text { thd })_{2}(90)$ & $\mathrm{O}_{3}$ & $\mathrm{Si}, \mathrm{Qz}$ & $200-300$ & 0.32 & Air-600 & {$[193]$} \\
\hline $\mathrm{CuCrO}_{2}$ & $\mathrm{Cu}(\text { thd })_{2}(120) ; \mathrm{Cr}(\mathrm{acac})_{3}(130)$ & $\mathrm{O}_{3}$ & $\mathrm{Si} / \mathrm{SiO}, \mathrm{BSG}$ & $200-270$ & 2.2 & Ar- 800 & [194] \\
\hline $\mathrm{CuAlO}_{2}$ & $\mathrm{Cu}(\mathrm{acac})_{2}(140) ; \mathrm{Al}\left(\mathrm{CH}_{3}\right)_{3}$ (NA) & $\mathrm{O}_{3}$ & $\mathrm{Qz}, \mathrm{AlO}$ & 200 & 1.15 & $\mathrm{~N}_{2}-1050$ & {$[195]$} \\
\hline $\mathrm{CuYO}_{2}$ & $\mathrm{Cu}(\mathrm{acac})_{2}(140) ; \mathrm{Y}(\mathrm{MeCp})_{3}$ & $\mathrm{H}_{2} \mathrm{O}$ & $\mathrm{AlO}$ & 200 & 1.5 & $\mathrm{~N}_{2}-1025$ & \\
\hline $\mathrm{Cu}(\mathrm{Cr}, \mathrm{Mg}) \mathrm{O}_{2}$ & $\begin{array}{l}\mathrm{Cu}(\text { thd })_{2}(120) ; \mathrm{Cr}(\mathrm{acac})_{3}(130) \\
\mathrm{Mg}(\text { thd })_{2}(150)\end{array}$ & $\mathrm{O}_{3}$ & $\mathrm{Si} / \mathrm{SiO}, \mathrm{BSG}$ & $200-270$ & $\sim 2.2$ & Ar-700 & {$[192]$} \\
\hline $\mathrm{CuCr}_{2} \mathrm{O}_{4}$ & $\mathrm{Cu}(\text { thd })_{2}(120) ; \mathrm{Cr}(\mathrm{acac})_{3}(130)$ & $\mathrm{O}_{3}$ & $\mathrm{Si} / \mathrm{SiO}, \mathrm{BSG}$ & $200-270$ & $\sim 2.2$ & Air-700 & [196] \\
\hline$(\mathrm{Co}, \mathrm{Ni})_{3} \mathrm{O}_{4}$ & $\mathrm{Co}(\text { thd })_{2}(90) ; \mathrm{Ni}(\text { thd })_{2}(115)$ & $\mathrm{O}_{3}$ & $\mathrm{Si} / \mathrm{SiO}, \mathrm{BSG}$ & 200 & 0.2 & As-dep. & [197] \\
\hline
\end{tabular}

\subsection{ALD of p-type Metal Sulfides}

Atomic layer deposition of metal sulfides is known since $1970 \mathrm{~s},{ }^{[198,199]}$ but in recent years there has been a renewed interest in the topic presumably driven by the potential applications of these materials in advanced photonic and energy technologies. The earth-abundant sulfide materials are of interest in solar cell applications as potential low-cost alternatives to silicon. Recently an excellent review of ALD of metal sulfides was written by Dasgupta et al. ${ }^{[200]}$ covering the photovoltaics, energy storage, and photonics applications. Here in the context of the present review we only report in Table 5 the ALD processes for the metal sulfides that are reported to be p-type semiconductors. Despite the vast ALD literature on metal sulfides, only a handful of the papers confirm the p-type semiconductivity for the films; the possible reason may be related to the inherent difficulties with sulfide ALD processes such as $\mathrm{H}_{2} \mathrm{~S}$ toxicity, air reactivity, and ion-exchange problems. ${ }^{[58,201,202]}$ However, with the recent advances in the field of ALD of metal chalcogenides it should be possible to find appropriate ways to overcome these problems. For example, ALD of sulfides has been successfully implemented over the past decade in each of the three roles common to most of the photovoltaic cells, i.e. absorber, emitter and buffer layer. ${ }^{[203-207]}$ 
Table 5. ALD processes reported for p-type semiconducting metal sulfides.

\begin{tabular}{|c|c|c|c|c|c|c|c|}
\hline \multirow{3}{*}{ Material } & \multicolumn{5}{|c|}{ Atomic Layer Deposition } & \multirow{3}{*}{$\begin{array}{c}\text { Cryst. } \\
\text { Req. }\end{array}$} & \multirow{3}{*}{ Ref. } \\
\hline & \multicolumn{2}{|c|}{ Precursor (Subl. temp. $\left({ }^{0} \mathrm{C}\right)$ ) } & \multirow{2}{*}{ Substrate } & \multirow{2}{*}{$\begin{array}{l}\text { Dep. Temp. } \\
\left({ }^{0} \mathrm{C}\right)\end{array}$} & \multirow{2}{*}{ GPC (Å) } & & \\
\hline & Precursor A & Precursor B & & & & & \\
\hline \multirow[t]{2}{*}{$\mathrm{Sb}_{2} \mathrm{Te}_{3}$} & \multirow[t]{2}{*}{$\mathrm{SbCl}_{3}(30-70)$} & $\left(\mathrm{Et}_{3} \mathrm{Si}\right)_{2} \mathrm{Te}(40-77)$ & $\mathrm{Si} / \mathrm{SiO}$ & $60-140$ & 0.17 & As-dep. & {$[19,208]$} \\
\hline & & $\left(\mathrm{Me}_{3} \mathrm{Si}\right)_{2} \mathrm{Te}(45)$ & $\mathrm{Si} / \mathrm{SiO}$ & $50-180$ & & As-dep. & [209] \\
\hline \multirow[t]{2}{*}{$\mathrm{SnS}$} & $\mathrm{Sn}(\mathrm{amd})_{2}(95)$ & $\mathrm{H}_{2} \mathrm{~S}$ & $\mathrm{SiO}$ & $100-300$ & $\begin{array}{l}0.86- \\
0.90\end{array}$ & As-dep. & {$[210,211]$} \\
\hline & $\mathrm{Sn}(\mathrm{acac})_{2}(105)$ & $\mathrm{H}_{2} \mathrm{~S}$ & $\mathrm{Si} / \mathrm{SiO}, \mathrm{BSG}, \mathrm{AlO}$ & $125-250$ & $\begin{array}{l}0.22- \\
0.24\end{array}$ & As-dep. & [212] \\
\hline \multirow[t]{3}{*}{$\mathrm{Cu}_{\mathrm{x}} \mathrm{S}$} & $\mathrm{Cu}(\text { thd })_{2}(115-120)$ & $\mathrm{H}_{2} \mathrm{~S}$ & $\mathrm{Si} / \mathrm{SiO}, \mathrm{BSG}, \mathrm{CG}$ & $125-250$ & $0.3-0.5$ & As-dep. & [213-215] \\
\hline & $\mathrm{Cu}_{2}(\mathrm{DBA})_{2}(160)$ & $\mathrm{H}_{2} \mathrm{~S}$ & $\mathrm{Qz}, \mathrm{ZrO}_{2}$ & 80 or 135 & & As-dep. & [216-218] \\
\hline & $\mathrm{Cu}(\mathrm{amd})_{2}(145)$ & $\mathrm{H}_{2} \mathrm{~S}$ & $\mathrm{Qz}, \mathrm{Si}$ & & 1.2 & As-dep. & [219] \\
\hline \multirow[t]{3}{*}{$\mathrm{PbS}$} & $\mathrm{Pb}(\text { thd })_{2}(120-175)$ & $\mathrm{H}_{2} \mathrm{~S}$ & \multirow{3}{*}{ BSG/AlO } & $130-390$ & $0.60-1.8$ & As-dep. & \multirow[t]{3}{*}[220-222]{} \\
\hline & $\begin{array}{l}\left(\mathrm{Pb}\left(\mathrm{OBu}^{\mathrm{t}}\right)_{2}\right)_{2} \text { or } 3 \\
(115-130)\end{array}$ & $\mathrm{H}_{2} \mathrm{~S}$ & & $130-390$ & 0.89 & As-dep. & \\
\hline & $\mathrm{Pb}(\text { dedtc })_{2}(210)$ & $\mathrm{H}_{2} \mathrm{~S}$ & & $220-340$ & $0.43-0.46$ & As-dep. & \\
\hline $\mathrm{CdS}$ & (DMCd) & $\mathrm{H}_{2} \mathrm{~S}$ & $\mathrm{Si} / \mathrm{SiO}, \mathrm{G}$ & $100-400$ & $1.92-0.72$ & As-dep. & [223] \\
\hline $\mathrm{In}_{2} \mathrm{~S}_{3}$ & $\operatorname{In}(\mathrm{acac})_{3}(120-150)$ & $\mathrm{H}_{2} \mathrm{~S}$ & $\mathrm{BSG}, \mathrm{SLG}, \mathrm{SnO}_{2} / \mathrm{SLG}$ & $130-260$ & $0.2-0.7$ & As-dep. & [224-227] \\
\hline \multirow[t]{2}{*}{$\mathrm{CuInS}_{2}$} & $\begin{array}{l}\mathrm{InCl}_{3}(300-345) \\
\mathrm{CuCl}_{(325-380)}\end{array}$ & $\mathrm{H}_{2} \mathrm{~S}$ & FTO, TiO & $350-500$ & & $S-450$ & \multirow[t]{2}{*}{$\begin{array}{l}{[203,228-} \\
230]\end{array}$} \\
\hline & $\begin{array}{l}\mathrm{Cu}(\mathrm{acac})_{2}(130) \\
\mathrm{In}(\mathrm{acac})_{3}(120)\end{array}$ & $\mathrm{H}_{2} \mathrm{~S}$ & BSG, Mo-SLG & $150-200$ & & S-450 & \\
\hline $\mathrm{Cu}_{\mathrm{x}} \mathrm{Al}_{\mathrm{y}} \mathrm{S}_{\mathrm{z}}$ & $\begin{array}{l}\mathrm{Cu}(\mathrm{acac})_{2}(130) \\
\mathrm{Al}\left(\mathrm{CH}_{3}\right)_{3}\end{array}$ & $\mathrm{H}_{2} \mathrm{~S}$ & BSG & $140-250$ & $0.1-0.3$ & & [231] \\
\hline $\mathrm{MnS}$ & $\mathrm{Mn}(\mathrm{EtCp})_{2}(100)$ & $\mathrm{H}_{2} \mathrm{~S}$ & $\mathrm{Si} / \mathrm{SiO}, \mathrm{Qz}$ & $100-225$ & $0.8-0.25$ & & [232] \\
\hline CZTS & $\begin{array}{l}\mathrm{Cu}_{2}(\mathrm{DBA})_{2}(160) \\
\mathrm{SnTDMA}(55) \\
\mathrm{Zn}\left(\mathrm{C}_{2} \mathrm{H}_{5}\right)_{2}\end{array}$ & $\mathrm{H}_{2} \mathrm{~S}$ & Qz, Si, FTO & 135 & & Ar-450 & $\begin{array}{l}{[204,233,} \\
234]\end{array}$ \\
\hline \multicolumn{8}{|c|}{ 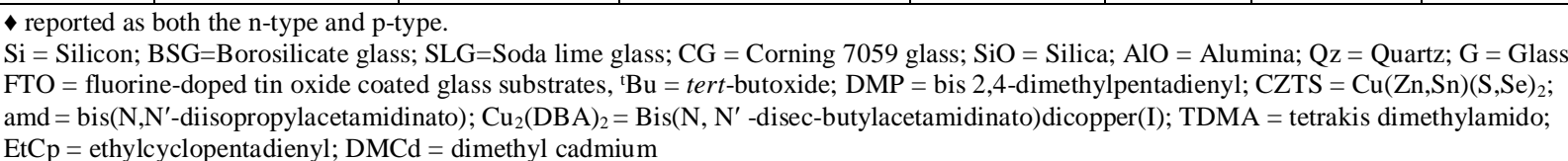 } \\
\hline
\end{tabular}

Theoretically, materials with bandgaps in the range of 1.0 to $1.6 \mathrm{eV}$ are expected to show a maximum power efficiency of $31-34 \%$ for single-absorber photovoltaics. Despite having a clear edge over metal oxides in terms of the bandgap, metal sulfides have not been widely explored. The ternary sulfide $\mathrm{CuInS}_{2}$ was the first solar absorber material successfully grown by ALD. ${ }^{[203]}$ It belongs to the popular chalcopyrite material family known as direct-bandgap high-extinction absorbers. Even though the other members of the family, including $\mathrm{CuInSe}_{2}, \mathrm{Cu}(\mathrm{In}, \mathrm{Ga}) \mathrm{Se}_{2}$ and $\mathrm{Cu}(\mathrm{In}, \mathrm{Ga})(\mathrm{S}, \mathrm{Se})_{2}$, have been reported to reach a power efficiency of $21 \%$ when deposited using other thin-film deposition techniques, similar ALD reports related to these materials are not found yet. At the same time it should be remembered that these materials contain scarce and expensive metals such as In and Ga, and may not be sustainable choices in a long run. Recently, ALD processes for thin films based on earth abundant material alternatives such as SnS and $\mathrm{Cu}(\mathrm{Zn}, \mathrm{Sn})(\mathrm{S}, \mathrm{Se})_{2}$ have been reported. So far the power efficiencies have remained low $(\sim 10 \%)$, but the systems certainly possess great potential to be scaled to terawatt levels. ${ }^{[204,211,235]}$ Cupric sulfide $\mathrm{Cu}_{2} \mathrm{~S}$ was extensively explored in the 1980 s for thin-film photovoltaic applications but a stable $\mathrm{Cu}_{2} \mathrm{~S}$ p-n junction is still elusive via conventional deposition techniques. Through ALD, though, highly stoichiometric, desirably doped $\left(10^{17} \mathrm{~cm}^{-3}\right)$ and oriented crystalline $\mathrm{Cu}_{2} \mathrm{~S}$ thin films have been fabricated. ${ }^{[216,218]}$ Moreover, using ALD-grown protective oxide overlayers the electronic properties of these films have been successfully stabilized against the oxidative effects of ambient exposure for at least one month which is promising considering the stable $\mathrm{Cu}_{2} \mathrm{~S}$ p-n junctions. ${ }^{\text {[219] }}$ 
Even though the stable $\mathrm{Cu}_{2} \mathrm{~S}$ PV device has yet to be demonstrated, ALD of p-type SnS has produced record efficiencies of $4 \%$ after co-optimization with ALD-grown $\mathrm{Zn}(\mathrm{O}, \mathrm{S}) .{ }^{[236]} \mathrm{Tin}(\mathrm{II})$ acetylacetonate in alternation with $\mathrm{H}_{2} \mathrm{~S}$ pulses produces lightly-doped $\left(10^{15} \mathrm{~cm}^{-3}\right)$ thin films with high mobilities up to $10 \mathrm{~cm}^{2} \mathrm{~V}^{-1} \mathrm{~s}^{-1}$. ${ }^{210-212]}$

\section{Electronic Transport and Optical Properties of the Films}

Despite the relatively large number of ALD processes developed for potential p-type semiconducting materials, very little is known about the electrical transport (electric conductivity, Seebeck coefficient and thermal conductivity) and optical properties of these thin films. One possible reason for the lack of such systematic and thorough characterization of the basic physical properties could be that the published works have typically concentrated on some specific application such as the use of the films in catalysis or sensors.

In Table 6 we summarize the room-temperature values of electrical resistivity, Seebeck coefficient and optical bandgap so far reported for the ALD-fabricated p-type semiconducting thin films. Particularly promising characteristics were recently realized for the delafossite-structured $\mathrm{CuCrO}_{2}$ and its $\mathrm{Mg}$-doped derivative. ${ }^{[192,194]}$ For the latter $\mathrm{Cu}(\mathrm{Cr}, \mathrm{Mg}) \mathrm{O}_{2}$ system, record-high p-type electrical conductivity $\left(220 \mathrm{~S} \mathrm{~cm}^{-1}\right)$ values - among the delafossite family - had been previously reported for thin films fabricated by PLD, but the transmittance values for these films in the visible range were as low as $\sim 40 \%$. ${ }^{[34]}$ Most importantly, for the $\mathrm{ALD}$-fabricated $\mathrm{Cu}(\mathrm{Cr}, \mathrm{Mg}) \mathrm{O}_{2}$ films the high electrical conductivity value $\left(217 \mathrm{~S} \mathrm{~cm}^{-1}\right)$ was accompanied with the high optical transparency of $\sim 80 \%$ (Figure 5).

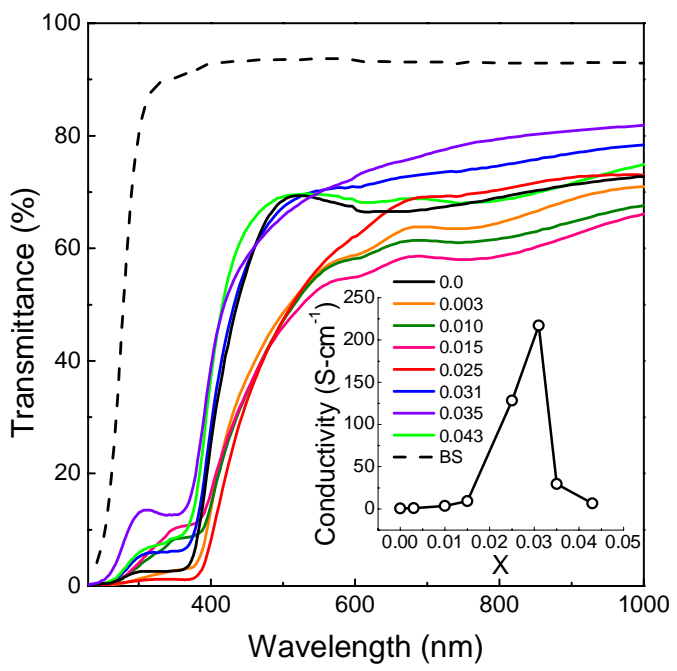

Figure 5. Transmittance spectra for the $\mathrm{Cu}\left(\mathrm{Cr}_{1-\mathrm{x}} \mathrm{Mg}_{\mathrm{x}}\right) \mathrm{O}_{2}$ films; the inset shows the room-temperature electrical conuctivity values with increasing $\mathrm{Mg}$ content $\mathrm{X} .{ }^{[192]}$ 
Table 6: Electrical transport and optical properties for ALD-grown p-type compound semiconductors.

\begin{tabular}{|c|c|c|c|c|c|c|c|}
\hline \multirow[b]{2}{*}{ Material } & \multirow[b]{2}{*}{ Precursors } & \multirow[b]{2}{*}{$\begin{array}{l}\text { Carrier conc. } \\
\quad\left(\mathrm{cm}^{-3}\right)\end{array}$} & \multirow[b]{2}{*}{$\begin{array}{l}\text { Mobility } \\
\left(\mathrm{cm}^{2} / \mathrm{V} \text {-s }\right)\end{array}$} & \multicolumn{2}{|c|}{ Electrical Transport } & \multirow{2}{*}{$\begin{array}{c}\text { Optical } \\
\text { gap } \\
\text { E (eV) }\end{array}$} & \multirow[b]{2}{*}{ Ref. } \\
\hline & & & & $\begin{array}{c}\mathbf{S} \\
(\mu \mathbf{V} / \mathbf{K})\end{array}$ & $\begin{array}{c}\rho \\
(\Omega \mathrm{cm})\end{array}$ & & \\
\hline \multirow[t]{4}{*}{$\mathrm{CuO}$} & $\mathrm{Cu}$ (thd $)_{2}, \mathrm{O}_{2}$ & & & & & & {$[66]$} \\
\hline & $\mathrm{Cu}(\text { thd })_{2} \mathrm{O}_{3}$ & & & +192 & $1-20$ & $1.06-1.24$ & {$[79,80]$} \\
\hline & $\mathrm{Cu}(\mathrm{acac})_{3}, \mathrm{O}_{3}$ & & & & 11 & & {$[81]$} \\
\hline & $\mathrm{Cu}(\mathrm{dmap})_{2}, \mathrm{O}_{3}$ & & & & $20-300$ & 1.11 & {$[82]$} \\
\hline \multirow[t]{3}{*}{$\mathrm{Cu}_{2} \mathrm{O}$} & $(\mathrm{hfac}) \mathrm{Cu}(\mathrm{I})(\mathrm{dmb}), \mathrm{O}_{3}$ & $\begin{array}{l}5.4 \times 10^{14}- \\
3.32 \times 10^{16}\end{array}$ & $12.9-37$ & & & $1.43-1.47$ & {$[84,85]$} \\
\hline & $\mathrm{Cu}(\mathrm{dmap})_{2}, \mathrm{H}_{2} \mathrm{O}$ & $5.88 \times 10^{14}$ & 8.05 & & & 2.52 & {$[92]$} \\
\hline & $\mathrm{Ni}\left({ }^{\mathrm{B} u}-\mathrm{MeAMD}\right)_{2}, \mathrm{H}_{2} \mathrm{O}$ & & & & & 3.52 & {$[112]$} \\
\hline \multirow[t]{2}{*}{$\mathrm{SnO}$} & $\mathrm{Sn}(\mathrm{dmamp})_{2}, \mathrm{H}_{2} \mathrm{O}$ & $3.4-16 \times 10^{17}$ & $0.4-2.9$ & & $4.9-14.5$ & $2.6-2.7$ & {$[113]$} \\
\hline & FeDMP, $\mathrm{O}_{2}, \mathrm{H}_{2} \mathrm{O}_{2}, \mathrm{O}_{3}$ & $3.02 \times 10^{17}$ & 1.34 & & 34 & & [159] \\
\hline \multirow[t]{3}{*}{$\mathrm{Co}_{3} \mathrm{O}_{4}$} & $\mathrm{CoI}_{2}, \mathrm{O}_{2}$ & & & & $0.13-85$ & & {$[162]$} \\
\hline & $\mathrm{Co}(\text { thd })_{2}, \mathrm{O}_{3}$ & & & & $0.13-4.48$ & & {$[172-174]$} \\
\hline & $\mathrm{Co}(\mathrm{Cp})_{2}, \mathrm{O}_{3}, \mathrm{O}_{2}$ plasma & & & & $0.55-5.3$ & & $\begin{array}{l}{[176-179,} \\
237]\end{array}$ \\
\hline$\left[\mathrm{CoCa}_{2} \mathrm{O}_{3}\right]_{q} \mathrm{CoO}_{2}$ & $\mathrm{Co}(\text { thd })_{2}, \mathrm{Ca}(\text { thd })_{2}, \mathrm{O}_{3}$ & & & $\begin{array}{l}+113 \\
+128\end{array}$ & 0.01 & & {$[193]$} \\
\hline $\mathrm{N}: \mathrm{ZnO}$ & $\mathrm{Zn}\left(\mathrm{C}_{2} \mathrm{H}_{5}\right)_{2}, \mathrm{NH}_{3}, \mathrm{H}_{2} \mathrm{O}$ & $1.59 \times 10^{17}$ & & & $2-17.9$ & & {$[181-183]$} \\
\hline $\mathrm{N}: \mathrm{TiO}_{2}$ & $\begin{array}{l}\mathrm{TiCl}_{4}, \mathrm{Ti}\left(\mathrm{N}\left(\left(\mathrm{CH}_{3}\right)_{2}\right)_{4}\right. \\
\mathrm{NH}_{3}, \mathrm{H}_{2} \mathrm{O}\end{array}$ & $7 \times 10^{14}-2 \times 10^{19}$ & $1.2-400$ & & $1.16 \times 10^{3}-6 \times 10^{-3}$ & $3.07-3.23$ & {$[115,116]$} \\
\hline \multirow[t]{3}{*}{$\mathrm{P}: \mathrm{ZnO}$} & $\mathrm{Zn}\left(\mathrm{C}_{2} \mathrm{H}_{5}\right)_{2}, \mathrm{P}\left(\mathrm{OCH}_{3}\right)_{3}, \mathrm{O}_{3}$ & $0.7-13 \times 10^{19}$ & $24-8.4$ & & $3 \times 10^{-3}$ & & {$[184]$} \\
\hline & $\mathrm{Zn}\left(\mathrm{C}_{2} \mathrm{H}_{5}\right)_{2}, \mathrm{H}_{2} \mathrm{O}, \mathrm{P}_{2} \mathrm{O}_{5}$ & $1.05 \times 10^{17}$ & & & 68.5 & & {$[185]$} \\
\hline & $\mathrm{Zn}\left(\mathrm{C}_{2} \mathrm{H}_{5}\right)_{2},\left(\mathrm{CH}_{3}\right)_{3} \mathrm{PO}_{4}, \mathrm{H}_{2} \mathrm{O}$ & & & & $2.5 \times 10^{-2}$ & & [186] \\
\hline $\mathrm{Cu}: \mathrm{ZnO}$ & $\mathrm{Zn}\left(\mathrm{C}_{2} \mathrm{H}_{5}\right)_{2}, \mathrm{Cu}(\mathrm{hfac})_{2}, \mathrm{H}_{2} \mathrm{O}$ & $16.7 \times \times 10^{19}$ & 14.2 & & $2.63 \times 10^{-3}$ & $3.36-3.27$ & [187] \\
\hline $\mathrm{CuCrO}_{2}$ & $\mathrm{Cu}(\text { thd })_{2}, \mathrm{Cr}(\mathrm{acac})_{3}, \mathrm{O}_{3}$ & & & +330 & 1.00 & 3.09 & [194] \\
\hline $\mathrm{CuAlO}_{2}$ & $\mathrm{Cu}(\text { thd })_{2}, \mathrm{TMA}, \mathrm{O}_{3}$ & & & & $>10^{6}$ & & [195] \\
\hline $\mathrm{CuCr}_{2} \mathrm{O}_{4}$ & $\mathrm{Cu}(\text { thd })_{2}, \mathrm{Cr}(\mathrm{acac})_{3}, \mathrm{O}_{3}$ & & & +170 & 4 & & [196] \\
\hline $\mathrm{Sb}_{2} \mathrm{Te}_{3}$ & $\mathrm{SbCl}_{3},\left(\mathrm{Et}_{3} \mathrm{Si}\right)_{2} \mathrm{Te}$ & & & +146 & 0.01 & & {$[19,209]$} \\
\hline \multirow[t]{2}{*}{$\mathrm{SnS}$} & $\mathrm{Sn}(\mathrm{amd})_{2}, \mathrm{H}_{2} \mathrm{~S}$ & $0.69-1.1 \times 10^{16}$ & $0.82-15.3$ & & $60-700$ & $1.3-1.42$ & \multirow[t]{2}{*}{ [210-212] } \\
\hline & $\mathrm{Sn}(\mathrm{acac})_{2}, \mathrm{H}_{2} \mathrm{~S}$ & & & & & 1.87 & \\
\hline \multirow[t]{2}{*}{$\mathrm{Cu}_{\mathrm{x}} \mathrm{S}$} & $\mathrm{Cu}(\text { thd })_{2}, \mathrm{H}_{2} \mathrm{~S}$ & & & & $1 \times 10^{-4}$ & 1.7 & [213-215] \\
\hline & $\mathrm{Cu}_{2} \mathrm{DBA}, \mathrm{H}_{2} \mathrm{~S}$ & $0.1-10 \times 10^{19}$ & $4-5$ & & & 1.27 & [219] \\
\hline $\mathrm{CdS}$ & DMCd, $\mathrm{H}_{2} \mathrm{~S}$ & & & & & $2.2-2.42$ & {$[223]$} \\
\hline $\mathrm{In}_{2} \mathrm{~S}_{3}$ & $\mathrm{In}(\mathrm{acac})_{3}, \mathrm{H}_{2} \mathrm{~S}$ & $0.1-1 \times 10^{17}$ & & & & $2.0-2.7$ & {$[224-227]$} \\
\hline
\end{tabular}

Other recent results are for $\mathrm{CuO}$ films for which the electrical resistivity and Seebeck coefficient follow conventional semiconducting behavior, but an anomalous dependence of the optical bandgap on the film thickness was revealed. Generally, inverse-square-root dependence of the optical bandgap on the film thickness is expected, but for the ultrathin ALD $\mathrm{CuO}$ films a proportionalcubic-root dependence was observed. ${ }^{[79]}$

The misfit-layered cobalt oxide $\left[\mathrm{Ca}_{2} \mathrm{CoO}_{3}\right]_{0.62}\left[\mathrm{CoO}_{2}\right]$ has been known as an excellent p-type thermoelectric material in bulk form with the simultaneous high electrical conductivity, high Seebeck coefficient and low thermal conductivity. Also the thin films grown by ALD showed room-temperature Seebeck values of 113 and $128 \mu \mathrm{V} / \mathrm{K}$ for the oxygen-annealed and $\mathrm{N}_{2}$-annealed samples, respectively. Thus, with decreasing oxygen content, not only the lattice parameter c but also the Seebeck coefficient was found to increase. The electrical resistivity showed semiconducting temperature dependence with a value of $12 \mathrm{~m} \Omega \mathrm{cm}$ at room temperature for the oxygen-rich sample.

The main objective in the studies on $\mathrm{N}$ - and $\mathrm{P}$-doped $\mathrm{ZnO}$ films has been to induce p-type conductivity to enable the fabrication of homodiodes based on $\mathrm{ZnO}$. This has however been notoriously difficult for $\mathrm{ZnO}$ because of the high level of intrinsic carrier doping from oxygen vacancies and zinc interstitial defects. Nonetheless, both nitrogen and phosphorus were successfully incorporated to turn ALD ZnO films into p-type, ${ }^{[182,184,185,238-240]}$ albeit a post-deposition annealing was required to remove the n-type carrier doping from defects and donor impurities. The major drawback for the fabrication of homodiodes is the higher resistivity of the p-type $\mathrm{ZnO}$ films compared to n-type $\mathrm{ZnO}$ films. Another topic of debate has been the longevity of the p-type doping, although the p-type behavior of $\mathrm{P}: \mathrm{ZnO}$ films was confirmed to remain stable for three months. ${ }^{[184]}$ 
Very recently $\mathrm{TiO}_{2}$ - a well-known intrinsically n-type TCO material due to oxygen vacancies and/or titanium interstitials ${ }^{[241,242]}$ - was fabricated as p-type films by ALD both without external doping and with nitrogen doping. ${ }^{[115,116]}$ However, the origin of the uncommon p-type conductivity in the two cases seemed not to be the same. In the former un-doped case the p-type doping was assigned to be due to excess oxygen, ${ }^{[116]}$ while in the latter $\mathrm{N}$-doped case due to titanium vacancies. ${ }^{[115]}$ Nonetheless, these films showed promising electrical and optical properties (Table 6), and even homodiodes were fabricated using them (Figure 6).
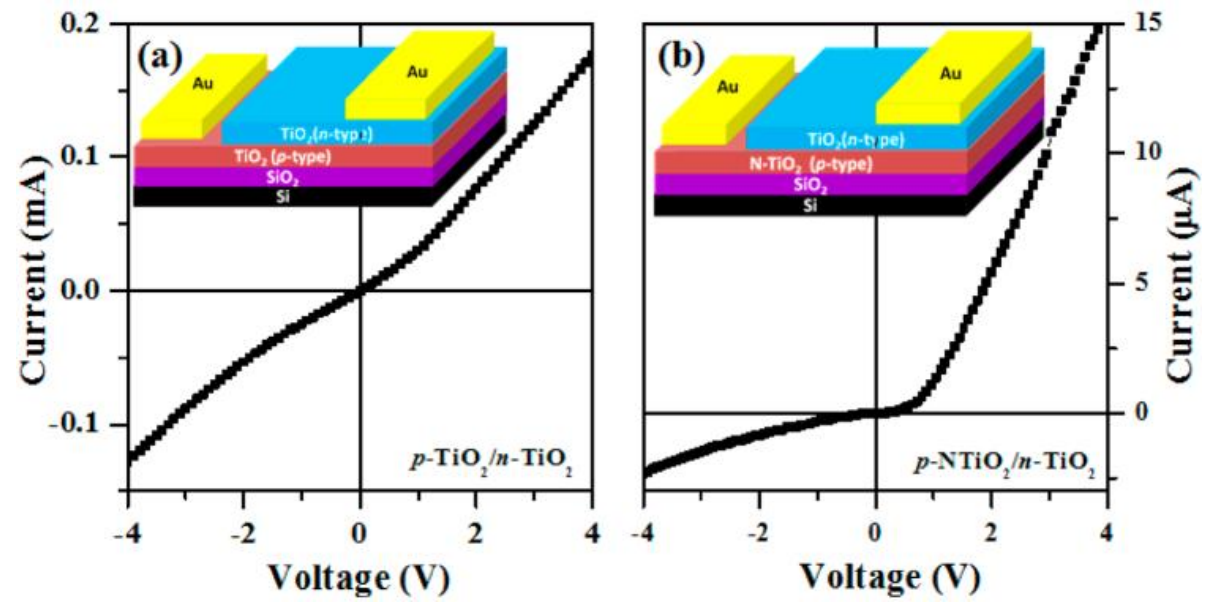

Figure 6. $\mathrm{I}-\mathrm{V}$ characteristics for the $\mathrm{p}-\mathrm{n}$ junctions of $\mathrm{ALD}$-fabricated (a) $\mathrm{p}-\mathrm{TiO}_{2} / \mathrm{n}-\mathrm{TiO}_{2}$, and (b) $\mathrm{p}$ $\mathrm{N}: \mathrm{TiO}_{2} / \mathrm{n}-\mathrm{TiO}_{2}$ devices; the device architecture in both cases is shown in the inset; ${ }^{[115]}$ re-published with permission.

\section{Summary and Outlook}

In this brief review, we have discussed the present status and future potential of the atomic layer deposition technique for the fabrication of semiconducting and in particular so-called transparent conducting thin films with p-type doping.

The field of p-type transparent conducting oxides and related p-type compound semiconductors in general has witnessed a steady development since 1997 when Hosono and co-workers reported the simultaneous p-type semiconductivity and transparency for the $\mathrm{CuAlO}_{2}$ delafossite. Despite this progress, the overall performance of transparent $\mathrm{p}$-type compound semiconductors is still far behind the best performances of their n-type counterparts. The leading strategy to achieve the superior $\mathrm{p}$ type TCO performance has been to look for materials where the holes of the top of the valence band could be delocalized through enhanced hybridization between the oxygen $2 p$ and metal cation $d$ orbitals. As the more recent design approaches, anions with the more delocalized $p$-orbitals such as $\mathrm{S}^{2-}, \mathrm{Se}^{2-}$ and $\mathrm{P}^{3-}$, and post-transition metals with $n s^{2}$ lone-pair states such as $\mathrm{Sn}^{2+}, \mathrm{Pb}^{2+}$ and $\mathrm{Bi}^{3+}$, have been explored as constituents for the next-generation p-type TCO materials. Also, highthroughput computational screening could provide us with new insights into the rational material design, as was recently demonstrated by Hautier et al. ${ }^{[243]}$ and Yan et al. ${ }^{[244]}$ who identified e.g. the $\mathrm{Ba}_{2} \mathrm{BiTaO}_{6}$ and TaIrGe phases as new promising p-type TCO material candidates.

Atomic layer deposition has already established its position as the state-of-the-art thin-film technology in microelectronics, and as the demands for e.g. portability and complexity in many other frontier applications, particularly in invisible or transparent electronics and flextronics (flexible electronics), are continuously increasing, the uniquely advantageous ALD technique can be foreseen to play a major role in these new demanding applications as well. The p-type (transparent) semiconductor materials hold great promise not only in the transparent electronics but also in a number of other advanced applications such as low-power electronics, display applications, memories, gas sensors, electrochromics and photovoltaics. For these applications the great potential of ALD has not been fully harnessed yet, even though there are already promising 
ALD processes developed for p-type conducting materials with encouraging performances. In future, similar approaches as developed for p-type $\mathrm{TiO}_{2}$ films to fabricate transparent homodiodes could be explored for these new ALD-fabricated p-type conducting materials. The delafossite family of compounds is one of the obvious candidate systems for these efforts, as there are both promising p-type phases (starting from the $\mathrm{CuAlO}_{2}$ prototype) and compatible n-type phases (e.g. $\mathrm{CuInO}_{2}$ and $\mathrm{AgInO}_{2}$ ) known within the family, with elemental compositions that are highly relevant to the ALD technology.

For the p-type semiconductors to find a widespread adoption, several key issues need to be addressed. To name a few, the off-state current in p-type oxide TFTs is very high compared with the case of the n-type semiconductors, and must hence be reduced. This could be achieved by exploiting strategies that improve the semiconductor growth process and reduce interfacial defects that are notoriously common in p-type oxides. In this regard, depositing capping/passivating layers by ALD could be highly advantageous. Such ultrathin capping/passivating coatings is an area where ALD has in general contributed immensely to improve the interfacial properties of $p$-n junction devices. For example by reducing the interface defect density of Si by a thin passivation layer of $\mathrm{Al}_{2} \mathrm{O}_{3}$, the efficiency of $\mathrm{Si}$ solar cells has been significantly enhanced. ${ }^{[245]}$ Similarly, very recently Kim et al. ${ }^{[114]}$ reported enhanced p-type TFT performance for ALD-grown SnO films by surface passivation of the back-channel active layer of the device with an ALD-grown $\mathrm{Al}_{2} \mathrm{O}_{3}$ coating. Another advantage of ALD is that the films can be fabricated at relatively low temperatures. This is highly useful for flexotronics applications. The low deposition temperature is beneficial also for avoiding the native vacancy/interstitial defects in p-type oxides thus promoting the enhanced electrical and optical properties of these materials, as was the case for example with the p-type delafossite $\mathrm{Cu}(\mathrm{Cr}, \mathrm{Mg}) \mathrm{O}_{2}$ thin films; here the electrical and optical functionalities were strongly enhanced for the ALD-fabricated films compared to the films prepared by conventional deposition techniques. ${ }^{[192]}$ With the ever decreasing scale of many novel applications, the high degree of conformality that can be achieved with ALD will further increase the importance of the technology in the coming years.

\section{Acknowledgement}

This work has been supported by the Strategic Research Council at the Academy of Finland (grant number 303452) and also by the Mineral Resources and Material Substitution Programme of the Academy of Finland (grant number 292431). 


\section{References}

[1] E. Fortunato, R. Martins, Phys. Status Solidi RRL 2011, 5, 336.

[2] Y. Ogo, H. Hiramatsu, K. Nomura, H. Yanagi, T. Kamiya, M. Hirano, H. Hosono, Appl. Phys. Lett. 2008, 93, 032113.

[3]Y. Ogo, H. Hiramatsu, K. Nomura, H. Yanagi, T. Kamiya, M. Kimura, M. Hirano, H. Hosono, Phys. Status Solidi A 2009, 206, 2187.

[4] E. Thimsen, A. B. F. Martinson, J. W. Elam, M. J. Pellin, J. Phys. Chem. C 2012, 116, 16830.

[5] M. Lorenz, M. S. Ramachandra Rao, T. Venkatesan, E. Fortunato, P. Barquinha, R. Branquinho, D. Salgueiro, R. Martins, E. Carlos, A. Liu, F. K. Shan, M. Grundmann, H. Boschker, J. Mukherjee, M. Priyadarshini, N. DasGupta, D. J. Rogers, F. H. Teherani, E. V. Sandana, P. Bove, K. Rietwyk, A. Zaban, A. Veziridis, A. Weidenkaff, M. Muralidhar, M. Murakami, S. Abel, J. Fompeyrine, J. Z.-Perez, R. Ramesh, N A Spaldin, S. Ostanin, V. Borisov, I. Mertig, V. Lazenka, G. Srinivasan, W. Prellier, M. Uchida, M. Kawasaki, R. Pentcheva, P. Gegenwart, F. M. Granozio, J. Fontcuberta, N. Pryds, J. Phys. D: Appl. Phys. 2016, 49, 433001.

[6] Z. Wang, P. K. Nayak, A. Albar, N. Wei, U. Schwingenschlögl, H. N. Alshareef, Adv. Mater. Interfaces 2015, 2, 1500374.

[7] Transparent electronics edited by J. F. Wager, D. A. Keszler, R. E. Presley, 2007, published by Springer Science \& Business Media, Berlin, Germany.

[8] M. Grundmann, R. Karsthof, H. von Wenckstern, ACS Appl. Mater. Interfaces 2014, 614785.

[9] M. Grundmann, F. Klüpfel, R. Karsthof, P. Schlupp, F.-L. Schein, D. Splith, C. Yang, S. Bitter, H. von Wenckstern, J. Phys. D: Appl. Phys. 2016, 49, 213001.

[10] H.-S. Kim, S. H. Jeon, J. S. Park, T. S. Kim, K. S. Son, J.-B. Seon, S.-J. Seo, S.-J. Kim, E. Lee, J. G. Chung, H. Lee, S. Han, M. Ryu, S. Y. Lee \& K. Kim, Sci. Rep. 2013, 3, 1459.

[11] K. Ellmer, Nature Photonics 2012, 6, 809.

[12] F.-L. Schein, M. Winter, T. Böntgen, H. von Wenckstern, M. Grundmann, Appl. Phys. Lett. 2014, $104,022104$.

[13] C. Yang, M. Kneiß, F.-L. Schein, M. Lorenz, M. Grundmann, Sci. Rep. 2016, 6, 21937.

[14] O. T. Inal, A. E. Torma, Thin Solid Films 1979, 60, 157.

[15] Y. S. Kim, Y. Shimogaki, J. Vac. Sci. Technol. A 2001, 19 (5), 2642.

[16] S. Gandikota, S. Voss, R. Tao, A. Duboust, D. Cong, L. Chen, S. Ramaswami, D. Carl, Microelectron. Eng. 2000, 50, 547.

[17] Atomic Layer Deposition: Principles, Characteristics, and Nanotechnology Applications, 2nd edition, edited by T. Kääriäinen, D. Cameron, M.-L. Kääriäinen, A. Sherman, 2013, published by John Wiley \& Sons, Inc. Hoboken, New Jersy, and Scrivener Publishing LLC, Salem, Massachusetts, USA.

[18] Atomic Layer Deposition of Nanostructured Materials, edited by N. Pinna and M. Knez, 2012, published by Wiley-VCH Vellag \& Co, Weinheim, Germany.

[19] V. Pore, T. Hatanpää, M. Ritala, M. Leskelä, J. Am. Chem. Soc. 2009, 131, 3478.

[20] M. Ritala, M. Leskelä, in Handbook of Thin Film Materials, edited by H. S. Nalwa, Academic, San Diego, 2002, Vol. 1, pp. 103-159.

[21] C. Auth, et al. Symposium on VLSI Technology (VLSIT) 2012, 131.

[22] K. Baedeker, Ann. Phys., Lpz. 1907, 327, 749.

[23] J. J. Mudd, T. L. Lee, V. Munoz-Sanjose, J. Zuniga-Perez, D. Hesp, J. M. Kahk, D. J. Payne, R. G. Egdell, C. F. McConville, Phys. Rev. B 2014, 89, 035203.

[24] P. D. C. King, T. D. Veal, C. F. McConville, J. Zuniga-Perez, V. Munoz-Sanjose, M. Hopkinson, E. D. L. Rienks, M. F. Jensen, P. Hofmann, Phys. Rev. Lett. 2010, 104, 256803.

[25] M. A. McMaster 1947 (Libby-Owens-Ford) (filed 5 October 1942) US Patent 2429.

[26] T. Minami, Semicond. Sci. Technol 2005, 20, S35.

[27] K. P. Loh, Q. L. Bao, G. Eda, M. Chhowalla, Nat. Chem. 2010, 2, 1015. 
[28] T. Tynell, M. Karppinen, Semicond. Sci. Technol. 2014, 29, 043001.

[29] D.V. Nazarov, N.P. Bobrysheva, O.M. Osmolovskaya, M.G. Osmolovsky, V.M. Smirnov, Rev. Adv. Mater. Sci. 2015, 40, 262.

[30] G. Hautier, A. Miglio, G. Ceder, G. M. Rignanese, X. Gonze, Nat. Commun. 2013, 4, 2292.

[31] Z. Wang, P. K. Nayak, J. A. C.-Frescas, H. N. Alshareef, Adv. Mater. 2016, $28,3831$.

[32] H. Kawazoe, M. Yasukawa, H. Hyodo, M. Kurita, H. Yanagi, H. Hosono, Nature 1997, 389, 939.

[33] T. Arnold, et al., Phys. Rev. B 2009, 79, 075102.

[34] R. Nagarajan, A. D. Draeseke, A. W. Sleight, J. Tate, J. Appl. Phys. 2001, 89, 8022.

[35] H. Yanagi, T. Hase, S. Ibuki, K. Ueda, H. Hosono, Appl. Phys. Lett. 2001, 78, 1583.

[36] N. Duan, A. W. Sleight, M. K. Jayaraj, J. Tate, Appl. Phys. Lett. 2000, 77, 1325.

[37] H. Kawazoe, H. Yanagi, K. Ueda, H. Hosono, MRS Bull., 2008, 25, 28.

[38] R. Nagarajan, N. Duan, M. K. Jayaraj, J. Li, K. A. Vanaja, A. Yokochi, A. Draeseke, J. Tate, A. W. Sleight, Int. J. Inorg. Mater. 2001, 3, 265.

[39] M. Snure, A. Tiwari, Appl. Phys. Lett. 2007, 91, 092123.

[40] D. O. Scanlon, A. Walsh, G. W. Watson, Chem. Mater. 2009, 21, 4568.

[41] K. Ueda, S. Inoue, S. Hirose, H. Kawazoe, H. Hosono, Appl. Phys. Lett. 2000, 77, 2701.

[42] J. P. Allen, D. O. Scanlon, L. F. J. Piper, G. W. Watson, J. Mater. Chem. C 2013, 1, 8194.

[43] H. Hiramatsu, K. Ueda, H. Ohta, M. Hirano, T. Kamiya, H. Hosono, Appl. Phys. Lett. 2003, 82, 1048.

[44] K. Ueda, S. Inoue, H. Hosono, N. Sarukura, M Hirano, Appl. Phys. Lett. 2001, 78, 2333.

[45] M. L. Liu, L. B. Wu, Q. Huang, L. D. Chen, I. W. Chen, J. Appl. Phys. 2007, 102, 116108.

[46] M. Dekkers, G. Rijnders, D. H. A. Blank, Appl. Phys. Lett. 2007, 90, 3.

[47] A. Togo, F. Oba, I. Tanaka, K. Tatsumi, Phys. Rev. B 2006, 74, 195128.

[48] G. W. Watson, J. Chem. Phys. 2001, 114, 758.

[49] A. Walsh, G. W. Watson, Phys. Rev. B 2004, 70, 235114.

[50] K. H. L. Zhang, K. Xi, M. G. Blamire, R. G. Egdell, J. Phys.: Condens. Matter 2016, 28, 383002.

[51] P. P. Edwards, A. Porch, M. O. Jones, D. V. Morgan, R. M. Perks, Dalton Trans. 2004, 2995.

[52] E. Fortunato, P. Barquinha, R. Martins, Adv. Mater. 2012, 24, 2945.

[53] L. O. Grondahl, Rev. Mod. Phys. 1933, 5, 141.

[54] B. S. Li, K. Akimoto, A. Shen, J. Cryst. Growth 2008, 311, 1102 (2008).

[55] H. Sato, T. Minami, S. Takata, T. Yamada, Thin Solid Films 1993, 236, 27.

[56] H. Yanagi, H. Kawazoe, A. Kudo, M. Yasukawa, H. Hosono, J. Electroceram. 2000, 4, 407.

[57] H. Kawazoe, H. Yanagi, K. Ueda, H. Hosono, MRS Bull. 2000, 25, 28.

[58] R. L. Puurunen, J. Appl. Phys. 2005, 97, 121301.

[59] A. M. Shevjakov, G. N. Kuznetsova, V. B. Aleskovskii, Proceedings of the Second USSR Conference on High-Temperature Chemistry of Oxides, Leningrad, USSR, 26-29 November 1965, Nauka, Leningrad, USSR, published in 1967, pp. 149-155, in Russian.

[60] T. Suntola, J. Antson, U.S. Patent No. 4058430, 15 November 1977.

[61] T. Suntola, J. Antson, Finland Patent No. 52359, 10 September 1977.

[62] S. M. George, Chem. Rev. 2009, 110 (1), 111.

[63] M. Leskelä, M. Ritala, Angew. Chem. Int. Ed. 2003, 42, 5548.

[64] V. Miikkulainen, M. Leskelä, M. Ritala, R. L. Puurunen, J. Appl. Phys. 2013, 113, 021301.

[65] R. M. Costescu, D. G. Cahill, F. H. Fabreguette, Z. A. Sechrist, S. M. George, Science 2004, 303, 989.

[66] S. Haukka, T. Suntola, Interface Sci. 1997, 5, 119.

[67] Atomic Layer Deposition for Semiconductors, edited by C. S. Hwang, 2014, published by Springer, New York, U.S A. 
[68] N. A. Stafforda, R. Katamreddy, L. Guerin, B. Feist, C. Dussarrat, V. Pallem, C. Weiland, R. Opila, ECS Trans. 2009, 19, 525.

[69] X. Ji, K. T. Lee, L. F. Nazar, Nat. Mater. 2009, 8, 500.

[70] S. K. Cheah, E. Perre, M. Rooth, M. Fondell, A. Hårsta, L. Nyholm, M. Boman, T. Gustafsson, J. Lu, P. Simon, K. Edström, Nano Lett. 2009, 9 (9), 3230.

[71] X. Meng, K. He, D. Su, X. Zhang, C. Sun, Y. Ren, H. H. Wang, W. Weng, L. Trahey, C. P. Canlas, J. W. Elam, Adv. Funct. Mater. 2014, 24, 5435.

[72] X. Meng, J. A. Libera, T. T. Fister, H. Zhou, J. K. Hedlund, P. Fenter, J. W. Elam, Chem. Mater. 2014, 26, 1029.

[73] Y. Çimen, A. W. Peters, J. R. Avila, W. L. Hoffeditz, S. Goswami, O. K. Farha, J. T. Hupp, Langmuir 2016, 32 (46), 12005.

[74] D. H. Kwon, Z. Jin, S. Shin, W.-S. Lee, Y.-S. Min, Nanoscale 2016, 8, 7180.

[75] J. S. King, C. W. Neff, C. J. Summers, W. Park, S. Blomquist, E. Forsythe, D. Morton, Appl. Phys. Lett. 2003, 83, 2566.

[76] W. Niu, X. Li, S. K. Karuturi, D. W. Fam, H. Fan, S. Shrestha, L. H. Wong, A. I. Y. Tok, Nanotechnology 2015, 26, 064001.

[77] P. Sundberg, M. Karppinen, Beilstein J. Nanotechnol. 2014, 5, 1104.

[78] P. Schlupp, F.-L. Schein, H. von Wenckstern, M. Grundmann, Adv. Electr. Mater. 2015, 1, 1400023.

[79] T. S. Tripathi, I. Terasaki, M. Karppinen, J. Phys.: Cond. Matter 2016, 28, 475801.

[80] G. Wang, G. Ran, G. Wan, P. Yang, Z. Gao, S. Lin, C. Fu, Y. Qin, ACS Nano 2014, 8, 5330.

[81] M. E. Alnes, E. Monakhov, H. Fjellvåg, O. Nilsen, Chem. Vap. Dep. 2012, 18, 173.

[82] T. Iivonen, J. Hämäläinen, B. Marchand, K. Mizohata, M. Mattinen, G. Popov, J. Kim, R., A. Fischer, M. Leskelä, J. Vac. Sci. Technol. A 2016, 34, 01 A109.

[83] K. Uwai, J. Cryst. Growth 1991, 112, 298.

[84] W. Maeng, S. H. Lee, J. D. Kwon, J. Park, J. S. Park, Ceram. Int. 2016, 42, 5517.

[85] J. D. Kwon, S. H. Kwon, T. H. Jung, K. S. Nam, K. B. Chung, D. H. Kim, J. S. Park, Appl. Surf. Sci. 2013, 285P, 373.

[86] T. Waechtler, S. Oswald, N. Roth, A. Jakob, H. Lang, R. Ecke, S. E. Schulz, T. Gessner, A. Moskvinova, S. Schulze, M. Hietschold, J. Electrochem. Soc. 2009, 156, H453.

[87] T. Waechtler, S. F. Ding, L. Hofmann, R. Mothes, Q. Xie, S. Oswald, C. Detavernier, S. E. Schulz, X. P. Qu, H. Lang, T. Gessner, Microelectron. Eng. 2011, 88, 684.

[88] T. Waechtler, N. Roth, R. Mothes, S. Schulze, S. E. Schulz, T. Gessner, H. Lang, M. Hietschold, ECS Trans. 2009, 25, 277.

[89] M. Fronk, S. Müller, T. Waechtler, S. E. Schulz, R. Mothes, H. Lang, D. R.T. Zahn, G. Salvan, Thin Solid Films 2012, 520, 4741.

[90] D. Dhakal, K. Assim, H. Lang, P. Bruener, T. Grehl, C. Georgi, T. Waechtler, R. Ecke, S. E. Schulz, T. Gessner, J. Vac. Sci. Technol. A 2016, 34, $01 \mathrm{~A} 111$.

[91] D. Dhakal, T. Waechtler, S. E. Schulz, T. Gessner, H. Lang, R. Mothes, A. Tuchscherer, J. Vac. Sci. Technol. A 2014, 32, 041505.

[92] H. Kim, M. Y. Lee, S. H. Kim, S. I. Bae, K. Y. Ko, H. Kim, K. W. Kwon, J. H. Hwang, D. J. Lee, Appl. Surf. Sci. 2015, 349, 673.

[93] D. M.-Rojas, M. Jordan, C. Yeoh, A. T. Marin, A. Kursumovic, L. A. Dunlop, D. C. Iza, A. Chen, H. Wang, J. L. M. Driscoll, AIP Adv. 2012, 2, 042179.

[94] M. Utriainen, M. K. Laukkanen, L. Niinistö, Mater. Sci. Eng. 1998, B54, 98.

[95] M. Utriainen, M. K. Laukkanen, L. S. Johansson, L. Niinistö, Appl. Surf. Sci. 2000, 157, 151 (2000).

[96] T. S. Yang, W. T. Cho, M. Kim, K. S. An, T. M. Chung, C. G. Kim, Y. Kim, J. Vac. Sci. Technol. A 2005, 23, 1238.

[97] J. H. Yang, S. Y. Lee, W. S. Song, Y. S. Shin, C. Y. Park, H. J. Kim, W. Cho, K. S. An, J. Vac. Sci. Technol. B 2008, 26, 1021. 
[98] Y.-H. You, B.-S. So, J.-H. Hwang, W. Cho, S. S. Lee, T.-M. Chung, C. G. Kim, K.-S. An, Appl. Phys. Lett. 2006, 89, 222105.

[99] H. Kumagai, M. Matsumoto, K. Toyoda, M. Obara, J. Mater. Sci. Lett. 1996, 15, 1080.

[100] B.-S. So, Y.-H. You, K.-H. Kim, J. Hwang, W. Cho, S. S. Lee, T.-M. Chung, Y. K. Lee, C. G. Kim, K.-S. An, Y.-C. Kim, Y.-H. Lee, W.-S. Seo, Electrochem. Solid-State Lett. 2007, 10, J61.

[101] S. Seo, I. J. Park, M. Kim, S. Lee, C. Bae, H. Suk J. N. G. Park, J. Y. Kim, H. Shin, Nanoscale 2016, 8,11403 .

[102] H. L. Lu, G. Scarel, C. Wiemer, M. Perego, S. Spiga, M. Fanciulli, G. Pavia, J. Electrochem. Soc.

2008, 155, H807.

[103] H. L. Lu, G. Scarel, X. L. Li, M. Fanciulli, J. Cryst. Growth 2008, 310, 5464.

[104] S. Spiga, A. Lamperti, C. Wiemer, M. Perego, E. Cianci, G. Tallarida, H. L. Lu, M. Alia, F. G. Volpe, and M. Fanciulli, Microelectron. Eng. 2008, 85, 2414.

[105] A. Lamperti, S. Spiga, H. L. Lu, C. Wiemer, M. Perego, E. Cianci, M. Alia, M. Fanciulli, Microelectron. Eng. 2008, 85, 2425.

[106] A. Pereira, J. L. Palma, J. C. Denardin, J. Escrig, Nanotechnol. 2016, 27, 345709.

[107] J. Chae, H.-S. Park, S.-W. Kang, Electrochem. Solid-State Lett. 2002, 5, C64.

[108] L. Yu, G. Wang, G. Wan, G. Wang, S. Lin, X. Li, K. Wang, Z. Bai, Y. Xiang, Dalton Trans. 2016, 45, 13779 .

[109] E. Lindahl, M. Ottosson, J.-O. Carlsson, Chem. Vap. Dep. 2009, 15, 186.

[110] E. Lindahl, M. Ottosson, J.-O. Carlsson, Surf. Coat. Technol. 2010, 205, 710.

[111] E. Lindahl, J. Lu, M. Ottosson, J. O. Carlsson, J. Cryst. Growth 2009, 311, 4082.

[112] C.-C. Hsu, H.-W. Su, C.-H. Hou, J.-J. Shyue, F.-Y. Tsai, Nanotechnol. 2015, 26, 385201.

[113] J. H. Han, Y. J. Chung, B. K. Park, S. K. Kim, H.-S. Kim, C. G. Kim, T.-M. Chung, Chem. Mater. 2014, 26, 6088.

[114] S. H. Kim, I.-H. Baek, D. H. Kim, J. J. Pyeon, T.-M Chung, S.-H. Baek, J.-S. Kim, J. H. Han, S. K. Kim, J. Mater. Chem. C 2017, 5, 3139.

[115] K. Vasu, M. B. Sreedhara, J. Ghatak, C. N. R. Rao, ACS Appl. Mater. Interfaces 2016, 8, 7897.

[116] A. T. Iancu, M. Logar, J. Park, F. B. Prinz, ACS Appl. Mater. Interfaces, 2015, 7, 5134.

[117] O. Nilsen, H. Fjellvåg, A. Kjekshus, Thin Solid Films, 2003, 444, 44.

[118] O. Nilsen, M. Peussa, H. Fjellvåg, L. Niinistö, A. Kjekshus, J. Mater. Chem., 1999, 9, 1781.

[119] F. Mattelaer, P. M. Vereecken, J. Dendooven, C. Detavernier, Chem. Mater. 2015, 27, 3628.

[120] H. Jin, D. Hagen, M. Karppinen, Dalton Trans. 2016, 45, 18737.

[121] M. Aronniemi, J. Sainio, J. Lahtinen, Thin Solid Films 2008, 516, 6110.

[122] J. A. Klug, N. G. Becker, S. C. Riha, A. B. F. Martinson, J. W. Elam, M. J. Pellin, T. Proslier, J. Mater. Chem. A 2013, 1, 11607.

[123] M. Rooth, A. Johansson, K. Kukli, J. Aarik, M. Boman, A. Hårsta, Chem. Vap. Dep. 2008, 14, 67.

[124] I. L. Soroka, M. Rooth, J. Lu, M. Boman, P. Svedlindh, J.-O. Carlsson, A. Hårsta, J. Appl. Phys. 2009, $106,084313$.

[125] J. R. Scheffe, A. Frances, D. M. King, X. Liang, B. A. Branch, A. S. Cavanagh, S. M. George, A. W. Weimer, Thin Solid Films 2009, 517, 1874.

[126] Y. Zhang, M. Liu, Y. Zhang, X. Chen, W. Ren, Z.-G. Ye, J. Appl. Phys. 2015, 117, 17C743.

[127] X. Meng, M. Ionescu, M. N. Banis, Y. Zhong, H. Liu, Y. Zhang, S. Sun, R. Li, X. Sun, J. Nanopart. Res. 2011, 13, 1207.

[128] J. R. Scheffe, M. D. Allendorf, E. N. Coker, B. W. Jacobs, A. H. McDaniel, A. W. Weimer, Chem. Mater. 2011, 23, 2030.

[129] Y. Zhang, M. Liu, B. Peng, Z. Zhou, X. Chen, S.-M. Yang, Z.-D. Jiang, J. Zhang, W. Ren, Z.-G. Ye, Scientific Reports 2016, 6, Article number 18401, DOI: 10.1038/srep18401. 
[130] J. Gemmer, Y. Hinrichsen, A. Abel, J. Bachmann, J. Catal. 2012, 290, 220.

[131] R. Zierold, Z. Y. Wu, J. Biskupek, U. Kaiser, J. Bachmann, C. E. Krill, K. Nielsch, Adv. Funct. Mater. 2011, 21, 226.

[132] B. M. Klahr, A. B. F. Martinson, T. W. Hamann, Langmuir 2011, 27, 461.

[133] J. Escrig, J. Bachmann, J. Jing, M. Daub, D. Altbir, K. Nielsch, Phys. Rev. B 2008, 77, 214421.

[134] A. B. F. Martinson, M. J. DeVries, J. A. Libera, S. T. Christensen, J. T. Hupp, M. J. Pellin, J. W. Elam, J. Phys. Chem. C 2011, 115, 4333.

[135] A. Tamm, M. C. Dimri, J. Kozlova, A. Aidla, T. Tatte, T. Arroval, U. M äeorg, H. Mandar, R. Stern, K. Kukli, J. Cryst. Growth 2012, 343, 21.

[136] S. C. Riha, M. J. D. Vermeer, M. J. Pellin, J. T. Hupp, A. B. F. Martinson, ACS Appl. Mater. Interfaces 2013, 5, 360.

[137] G. Wan, G. Wang, X. Huang, H. Zhao, X. Li, K. Wang, L. Yu, X. Penga, Yong Qin, Dalton Trans. 2015, 44, 18804.

[138] Q. Liu, F. Cao, F. Wu, H. Lu, L. Li, Adv. Mater. Interfaces 2016, 3, 1600256.

[139] G. Wang, Z. Gao, S. Tang, C. Chen, F. Duan, S. Zhao, S. Lin, Y. Feng, L. Zhou, Y. Qin, ACS Nano 2012, 6, 11009.

[140] K. Pitzschel, J. M. M. Moreno, J. Escrig, O. Albrecht, K. Nielsch, J. Bachmann, ACS Nano 2009, 3, 3463.

[141] O. Zandi, T. W. Hamann, J. Phys. Chem. Lett. 2014, 5, 1522.

[142] M. J. Pellin, S. C. Riha, E. C. Tyo, G. Kwon, J. A. Libera, J. W. Elam, S. Seifert, S. Lee, S. Vajda, ChemSusChem 2016, 9, 1.

[143] G. Wang, Z. Gao, G. Wan, S. Lin, P. Yang, Y. Qin, Nano Res. 2014, 7, 704.

[144] O. Zandi, B. M. Klahr T. W. Hamann, Energy Environ. Sci. 2013, 6, 634.

[145] B. Klahr, S. Gimenez, F. F.-Santiago, J. Bisquert, T. W. Hamann, J. Am. Chem. Soc. 2012, 134, 16693.

[146] O. Nilsen, M. Lie, S. Foss, H. Fjellvåg, A. Kjekshus, Appl. Surf. Sci. 2004, 227, 40.

[147] M. Lie, H. Fjellvåg, A. Kjekshus, Thin Solid Films, 2005, 488, 74.

[148] M. Lie, K. B. Klepper, O. Nilsen, H. Fjellvåg, A. Kjekshus, Dalton Trans. 2008, 253, DOI: $10.1039 / \mathrm{B} 711718 \mathrm{~N}$

[149] J. A. Libera, J. W. Elam, N. F. Sather, T. Rajh, N. M. Dimitrijevic, Chem. Mater. 2010, 22, 409.

[150] M. de Ridder, P. C. van de Ven, R. G. van Welzenis, H. H. Brongersma, S. Helfensteyn, C. Creemers,

P. Van Der Voort, M. Baltes, M. Mathieu, E. F. Vansant, J. Phys. Chem. B 2002, 106, 13146.

[151] K. Zhou, J.-Q. Huang, Q. Zhang, F. Wei, Nanoscale Res. Lett. 2010, 5, 1555.

[152] J. Bachmann, J. Escrig, K. Pitzschel, J. M. Montero Moreno, J. Jing, D. Goerlitz, D. Altbir, K. Nielsch, J. Appl. Phys. 2009, 105, 07B521.

[153] Y. J. Lin, S. Zhou, S. W. Sheehan, D. W. Wang, J. Am. Chem. Soc. 2011, 133, 2398.

[154] J. Bachmann, J. Jing, M. Knez, S. Barth, H. Shen, S. Mathur, U. G€osele, K. Nielsch, J. Am. Chem. Soc. 2007, 129, 9554.

[155] M. Daub, J. Bachmann, J. Jing, M. Knez, U. Gösele, S. Barth, S. Mathur, J. Escrig, D. Altbir, K. Nielsch, ECS Transact. 2007, 11, 139.

[156] Y. Lin, Y. Xu, M. T. Mayer, Z. I. Simpson, G. McMahon, S. Zhou, D. Wang, J. Am. Chem. Soc., 2012, $134,5508$.

[157] R. K. Ramachandran, J. Dendooven, C. Detavernier, J. Mater. Chem. A 2014, 2, 10662.

[158] J. R. Avila, D. W. Kim, M. Rimoldi, O. K. Farha, J. T. Hupp, ACS Appl. Mater. Interfaces 2015, 7, 16138.

[159] S. C. Riha, J. M. Racowski, M. P. Lanci, J. A. Klug, A. S. Hock, A. B. F. Martinson, Langmuir 2013, $29,3439$. 
[160] K. Kukli, M. C. Dimri, A. Tamm, M. Kemell, T. Käämbre, M. Vehkamäki, M. Puttaswamy, R. Stern, I. Kuusik, A. Kikas, M. Tallarida, D. Schmeißer, M. Ritala, M. Leskelä, ECS J. Solid State Sci. Technol.

2013, 2, N45.

[161] L. Steier, J. Luo, M. Schreier, M. T. Mayer, T. Sajavaara, M. Grätzel, ACS Nano 2015, 9, 11775.

[162] M. Rooth, E. Lindahl, A. Hårsta, Chem. Vap. Dep. 2006, 12, 209.

[163] L. B. Backman, A. Rautiainen, M. Lindblad, O. Jylhä, A. O. I. Krause, Appl. Catal. A 2001, 208, 223.

[164] L. B. Backman, A. Rautiainen, M. Lindblad, A. O. I. Krause, Appl. Catal. A, 2009, 360, 183.

[165] L. B. Backman, A. Rautiainen, M. Lindblad, A. O. I. Krause, Appl. Catal. A 2000, 191, 55.

[166] L. B. Backman, A. Rautiainen, A. O. I. Krause, M. Lindblad, Catal. Today 1998, 43, 11.

[167] V. G. Milt, M. A. Ulla, E. A. Lombardo, J. Catal. 2001, 200, 241.

[168] V. G. Milt, E. A. Lombardo, M. A. Ulla, Appl. Catal. B 2002, 37, 63.

[169] V. G. Milt, M. A. Ulla, E. A. Lombardo, Catal. Lett. 2000, 65, 67.

[170] R. L. Puurunen, T. A. Zeelie, A. O. I. Krause, Catal. Lett. 2002, 83, 27.

[171] A. Rautiainen, M. Lindblad, L. B. Backman, R. L. Puurunen, Phys. Chem. Chem. Phys. 2002, 4, 2466 (2002).

[172] H. Seim, M. Nieminen, L. Niinistö, H. Fjellvåg, L.-S. Johansson, Appl. Surf. Sci. 1997, 112, 24.

[173] K. B. Klepper, O. Nilsen, H. Fjellvåg, Thin Solid Films 2007, 515, 7772.

[174] K. B. Klepper, O. Nilsen, H. Fjellvåg, J. Cryst. Growth 2007, 307, 457.

[175] D. K. Nandi, J. Manna, A. Dhara, P. Sharma, S. K. Sarkar, J. Vac. Sci. Technol. A 2016, 34, 01 A115.

[176] M. E. Donders, H. C. M. Knoops, M. C. M. van de Sanden, W. M. M. Kessels, P. H. L. Notten, J. Electrochem. Soc. 2011, 158, G92.

[177] M. Diskus, O. Nilsen, H. Fjellvåg, Chem. Vap. Dep. 2011, 17, 135.

[178] B. Huang, W. Yang, Y. Wen, B. Shan, R. Chen, ACS Appl. Mater. Interfaces 2015, 7, 422.

[179] C. Guan, X. Qian, X. Wang, Y. Cao, Q. Zhang, A. Li, J. Wang, Nanotechnol. 2015, 26, 094001.

[180] B. Han, K. H. Choi, K. Park, W. S. Han, W.-J. Lee, Electrochem. Solid State Lett. 2012, 15, D14.

[181] C. Lee, J. Lim, J. Vac. Sci. Technol. A 2006, 24, 1031.

[182] C. Lee, S. Y. Park, J. Lim H. W. Kim, Mater. Lett. 2007, 61, 2495.

[183] L. Dunlop, A. Kursumovic, J. L. MacManus-Driscoll, Appl. Phys. Lett. 2008, 93, 172111.

[184] H. Yuan, B. Luo, S. A. Campbell, W. L. Gladfelter, Electrochem. Solid-State Lett. 2011, 14, H181.

[185] Y. T. Shih, J. F. Chien, M. J. Chen, J. R. Yang, M. Shiojiri, J. Electrochem. Soc. 2011, 158, H516.

[186] T. Tynell, R. Okazaki, I. Terasaki, H. Yamauchi, M. Karppinen, J. Mater. Sci. 2013, 48, 2806.

[187] S.-S. Xu, H.-L. Lu, Y. Zhang, T. Wang, Y. Geng, W. Huang, S.-J. Ding, D. W. Zhang, J. Alloys. Comp. 2015, 638, 133.

[188] L. Y. Liang, Z. M. Liu, H. T. Cao, Z. Yu, Y. Y. Shi, A. H. Chen, H. Z. Zhang, Y. Q. Fang, X. L. Sun, J. Electrochem. Soc. 2010, 157, H598.

[189] H. Yabuta, N. Kaji, R. Hayashi, H. Kumomi, K. Nomura, T. Kamiya, M. Hirano, H. Hosono, Appl. Phys. Lett. 2010, 97, 072111.

[190] E. Fortunato, R. Barros, P. Barquinha, V. Figueiredo, S.-H. K. Park, C.-S. Hwang, R. Martins, Appl. Phys. Lett. 2010, 97, 052105.

[191] K. Matsuzaki, K. Nomura, H. Yanagi, T. Kamiya, M. Hirano, and H. Hosono, Appl. Phys. Lett. 2008, 93, 202107.

[192] T. S. Tripathi, M. Karppinen, Adv. Electron. Mater. 2016, 1600341.

[193] J. Lybeck, M. Valkeapää, S. Shibasaki, I. Terasaki, H. Yamauchi, M. Karppinen, Chem. Mater. 2010, $22,5900$.

[194] T. S. Tripathi, J.-P. Niemelä, M. Karppinen, J. Mater. Chem. C 2015, 3, 8364. 
[195] M. E. Alnes, Transparent conducting oxides by atomic layer deposition, Väitöskirja, University of Oslo, Faculty of Mathematics and Natural Sciences, Oslo, 2015.

[196] T. S. Tripathi, C. S. Yadav, M. Karppinen, APL Mater. 2016, 4, 046106.

[197] D. J. Hagen, T. S. Tripathi, M. Karppinen, submitted, 2017.

[198] T. Suntola, J. Antson, U.S. Patent 19774058430.

[199] T. Suntola, J. Hyvarinen, Annu. Rev. Mater. Sci. 1985, 15, 177.

[200] N. P. Dasgupta, X. Meng, J. W. Elam, A. B. F. Martinson, Acc. Chem. Res. 2015, 48, 341.

[201] E. Thimsen, S. V. Baryshev, A. B. F. Martinson, J. W. Elam, I. V. Veryovkin, M. J. Pellin, Chem. Mater. 2013, 25, 313.

[202] P. Genevee, F. Donsanti, N. Schneider, D. Lincot, J. Vac. Sci. Technol. A, 2013, 31(1), A131.

[203] M. Nanu, L. Reijnen, B. Meester, J. Schoonman, A. Goossens, Chem. Vap. Deposition 2004, 10, 45.

[204] E. Thimsen, S. C. Riha, S. V. Baryshev, A. B. F. Martinson, J. W. Elam, M. J. Pellin, Chem. Mater. 2012, 24, 3188.

[205] T. P. Brennan, P. Ardalan, H. B. R. Lee, J. R. Bakke, I. K. Ding, M. D. McGehee, S. F. Bent, Adv. Energy Mater. 2011, 1, 1169.

[206] S. K. Sarkar, J. Y. Kim, D. N. Goldstein, N. R. Neale, K. Zhu, C. M. Elliot, A. J. Frank, S. M. George, J. Phys. Chem. C 2010, 114, 8032.

[207] J. R. Bakke, K. L. Pickrahn, T. P. Brennan, S. F. Bent, Nanoscale 2011, 3, 3482.

[208] S. Zastrow, J. Gooth, T. Boehnert, S. Heiderich, W. Toellner, S. Heimann, S. Schulz, K. Nielsch, Semicond. Sci. Technol. 2013, 28, 035010.

[209] D. Nminibapiel, K. Zhang, M. Tangirala, H. Baumgart, V. S. K. Chakravadhanula, C. Kübel, V. Kochergin, ECS J. Solid State Sci. Technol. 2014, 3, P95.

[210] S. B. Kim, P. Sinsermsuksakul, A. S. Hock, R. D. Pike, R. G. Gordon, Chem. Mater. 2014, 26, 3065.

[211] P. Sinsermsuksakul, J. Heo, W. Noh, A. S. Hock, R. G. Gordon, Adv. Energy Mater. 2011, 1, 1116.

[212] J. Y. Kim, S. M. George, J. Phys. Chem. C 2010, 114, 17597.

[213] J. Johansson, J. Kostamo, M. Karppinen, L. Niinistö, J. Mater. Chem. 2002, 12, 1022 (2002).

[214] L. Reijnen, B. Meester, A. Goossens, J. Schoonman, Chem. Vap. Dep. 2003, 9, 15.

[215] L. Reijnen, B. Meester, A. Goossens, J. Schoonman, Mater. Sci. Eng. C 2002, 19, 311.

[216] A. B. F. Martinson, S. C. Riha, E. Thimsen, J. W. Elam, M. J. Pellin, Energy Environ. Sci. 2013, 6, 1868 .

[217] E. Thimsen, Q. Peng, A. B. F. Martinson, M. J. Pellin, J. W. Elam, Chem. Mater. 2011, 23, 4411.

[218] A. B. F. Martinson, J. W. Elam, M. J. Pellin, Appl. Phys. Lett. 2009, 94, 123017.

[219] S. C. Riha, S. Jin, S. V. Baryshev, E. Thimsen, G. P. Wiederrecht, A. B. F. Martinson, ACS Appl. Mater. Interfaces 2013, 5, 10302.

[220] N. P. Dasgupta, S. P. Walch, F. B. Prinz, Electrochem. Soc. Trans. 2008, 16, 29.

[221] M. Leskelä, L. Niinistö, P. Niemelä, E. Nykänen, P. Soininen, M. Tiitta, J. Vähäkangas, Vacuum 1990, $41,1457$.

[222] E. Nykänen, J. Laine-Ylijoki, P. Soininen, L. Niinistö, M. Leskelä, L. G. Hubert-Pfalzgraf, J. Mater. Chem. 1994, 4, 1409.

[223] J. R. Bakke, H. J. Jung, J. T. Tanskanen, R. Sinclair, S. F. Bent, Chem. Mater. 2010, 22, 4669.

[224] P. Genevée, F. Donsanti, N. Schneider, D. Lincot, J. Vac. Sci. Technol. A 2013, 31, 01 A131.

[225] P. Genevée, F. Donsanti, G. Renou, D. Lincot, J. Phys. Chem. C 2011, 115, 17197.

[226] N. Naghavi, R. Henriquez, V. Laptev, D. Lincot, Appl. Surf. Sci. 2004, 222, 65.

[227] E. B. Yousfi, B. Weinberger, F. Donsanti, P. Cowache, D. Lincot, Thin Solid Films 2001, 387, 29.

[228] M. Nanu, J. Schoonman, A. Goossens, Adv. Funct. Mater. 2005, 15, 95.

[229] M. Nanu, L. Reijnen, B. Meester, A. Goossens, J. Schoonman, Thin Solid Films 2003, 431, 492. 
[230] N. Schneider, M. Bouttemy, P. Genevée, D. Lincot, F. Donsanti, Nanotechnol. 2015, 26, 054001. [231] L. Duclaux, F. Donsanti, J. Vidal, M. Bouttemy, N. Schneider, N. Naghavi, Thin Solid Films 2015, 594, 232.

[232] S. C. Riha, A. A. Koegel, X. Meng, I. S. Kim, Y. Cao, M. J. Pellin, J. W. Elam, A. B. F. Martinson, ACS Appl. Mater. Interfaces 2016, 8, 2774.

[233] E. Thimsen, S. C. Riha, S. V. Baryshev, A. B. F. Martinson, J. W. Elam, M. J. Pellin, Chem. Mater. 2013, 25, 313.

[234] S. V. Baryshev, S. C. Riha, A. V. Zinovev, Surf. Sci. Spectra 2015, 22, 81.

[235] T. K. Todorov, K. B. Reuter, D. B. Mitzi, Adv. Mater. 2010, 22, E156.

[236] P. Sinsermsuksakul, L. Sun, S. W. Lee, H. H. Park, S. B. Kim, C. Yang, R. G. Gordon, Adv. Energy Mater. 2014, 4, 1400496.

[237] H. B. Profijt, M. C. M. van de Sanden, W. M. M. Kessels, J. Vac. Sci. Technol. A 2013, 31, 01 A106.

[238] C. Lee, J. Lim, J. Vac. Sci. Technol. A 2006, 24, 1031.

[239] L. Dunlop, A. Kursumovic, J. L. MacManus-Driscoll, Appl. Phys. Lett. 2008, 93, 172111.

[240] H. S. Kim, D. H. Lee, S. J. Noh, J. Korean Phys. Soc. 2011, 58, 761.

[241] Design of Advanced Photocatalytic Materials for Energy and Environmental Applications, edited by J. M. Coronado, F. Fresno, M. D. Hernández-Alonso, R. Portela, 2013, published by Springer London, U.K.

[242] J.-P. Niemelä, G. Marin, M. Karppinen, Semicond. Sci. Technol., submitted 2017.

[243] G. Hautier, A. Miglio, G. Ceder, G. M. Rignanese and X. Gonze, Nat. Commun. 2013, 4, 2292.

[244] F. Yan, X. W. Zhang, Y. G. Yu, L. P. Yu, A. Nagaraja, T. O. Mason and A. Zunger, Nat. Commun. 2015, 67308.

[245] Atomic Layer Deposition in Energy Conversion Applications, edited by J. Bachmann, 2017, published by Wiley-VCH Vellag \& Co, Weinheim, Germany. 